\title{
DEVELOPMENT OF THE OPEN ITEMS TRACKING SYSTEM
}

\author{
Topical Report
}

By

Vito Riggi

June 1, 1994

Work performed Under Contract No. DE-AC07-81NE44139

Prepared for

U.S. Department of Energy

Assistant Secretary for Nuclear Energy

Prepared by

West Valley Nuclear Services Co., Inc.

P.O. Box 191

West Valley, New York 14171-0191

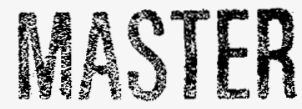

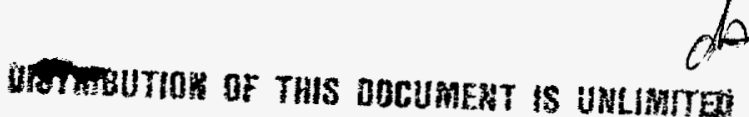




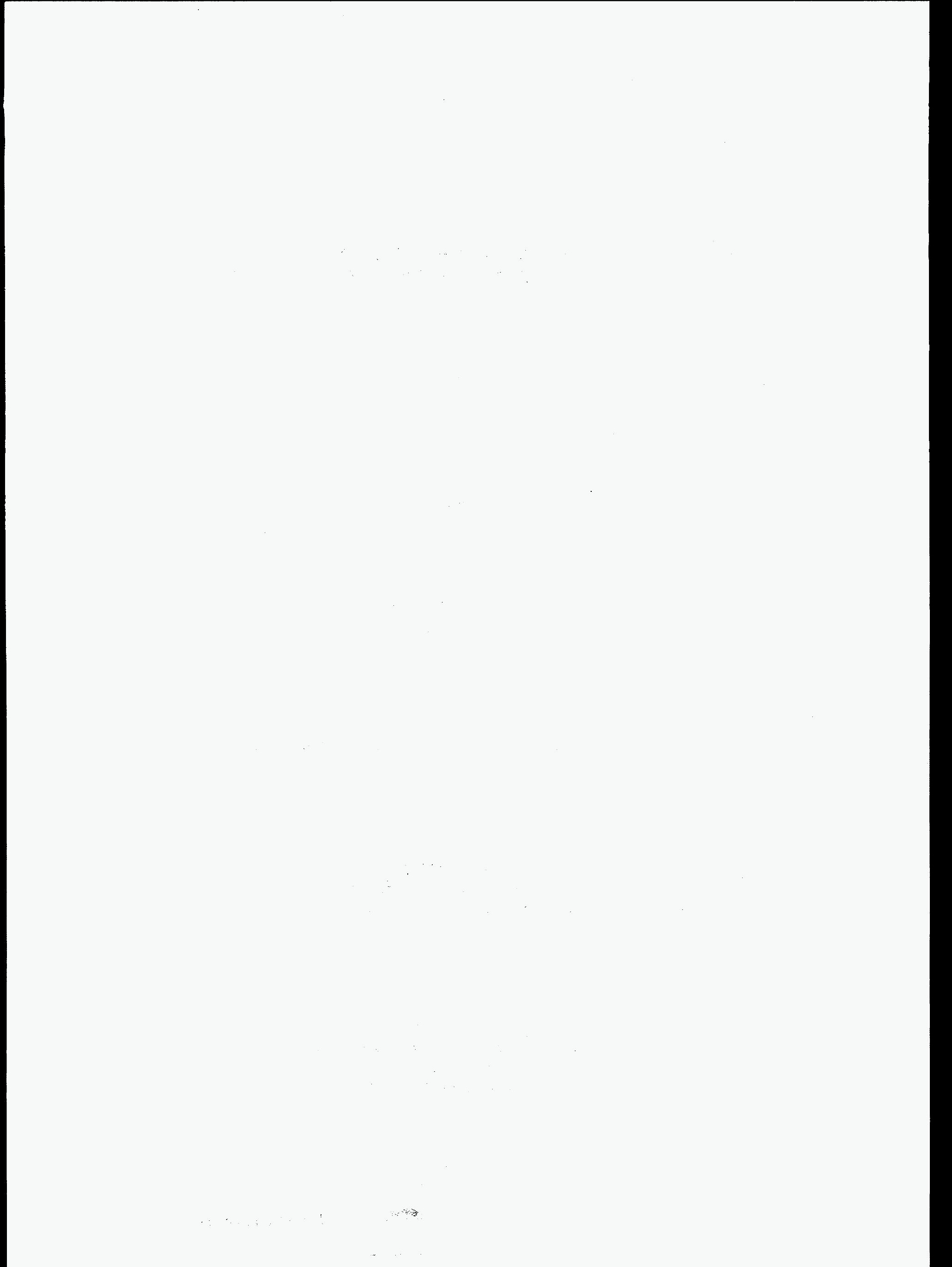




\section{DISCLAIMER}

This report was prepared as an account of work sponsored by an agency of the United States Government. Neither the United States Government nor any agency thereof, nor any of their employees, make any warranty, express or implied, or assumes any legal liability or responsibility for the accuracy, completeness, or usefulness of any information, apparatus, product, or process disclosed, or represents that its use would not infringe privately owned rights. Reference herein to any specific commercial product, process, or service by trade name, trademark, manufacturer, or otherwise does not necessarily constitute or imply its endorsement, recommendation, or favoring by the United States Government or any agency thereof. The views and opinions of authors expressed herein do not necessarily state or reflect those of the United States Government or any agency thereof. 


\section{DISCLAIMER}

Portions of this document may be illegible in electronic image products. Images are produced from the best available original document. 
Section

LIST OF FIGURES iv

EXECUTIVE SUMMARY $\ldots \ldots \ldots \ldots \ldots \ldots \ldots \ldots \ldots \ldots \ldots \ldots \ldots \ldots \ldots \ldots \ldots \ldots \ldots \ldots \ldots \ldots$

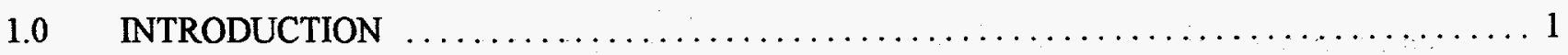

2.0 DEVELOPMENT OF THE OPEN ITEMS TRACKING SYSTEM $\ldots \ldots \ldots \ldots \ldots \ldots \ldots \ldots 2$

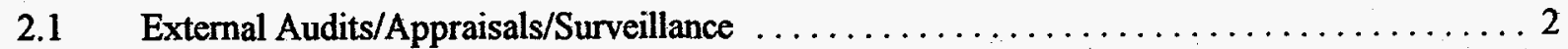

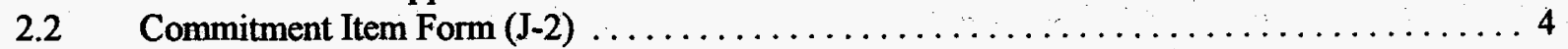

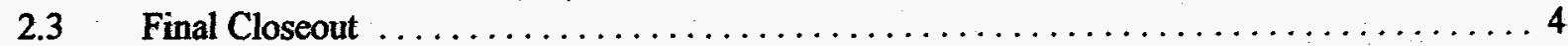

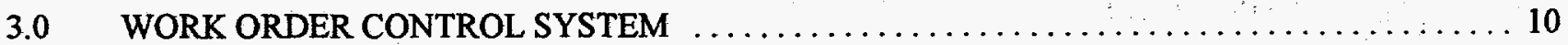

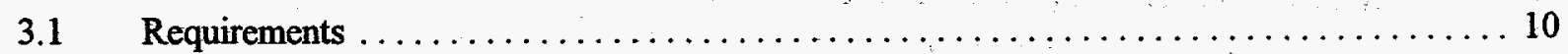

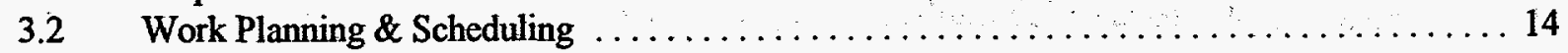

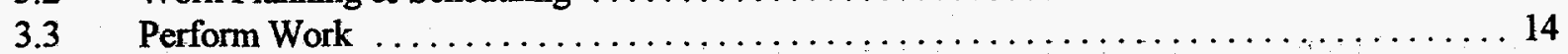

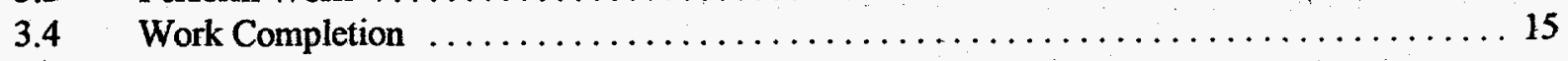

4.0 PREVENTIVE MAINTENANCE \& INSTRUMENT CALIBRATION RECALL SYSTEM $\ldots \ldots 17$

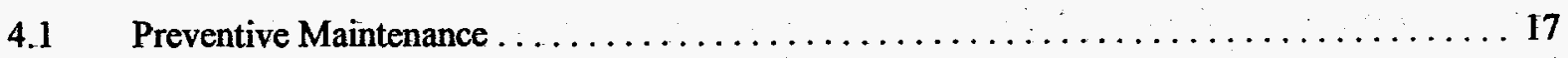

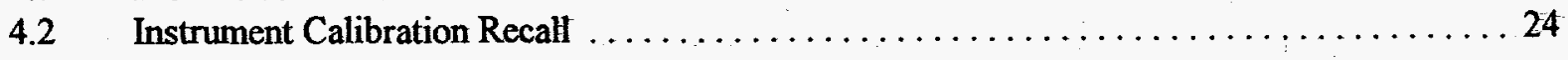

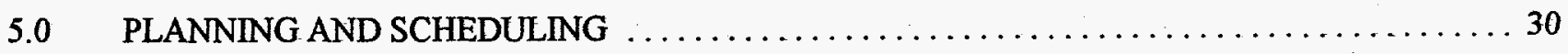

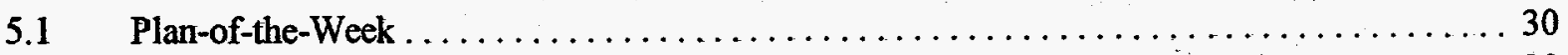

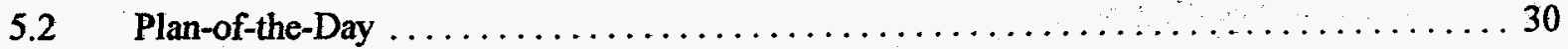

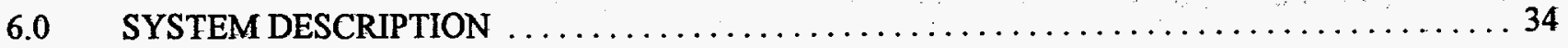

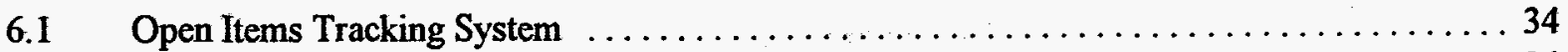

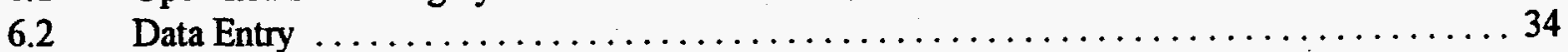

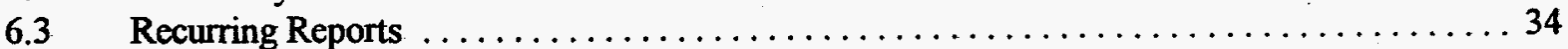

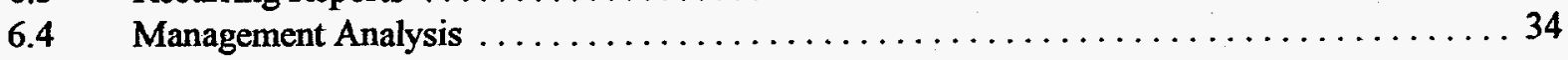




\section{LIST OF FIGURES}

Figure

Page

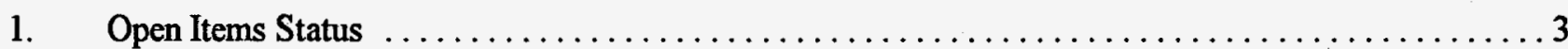

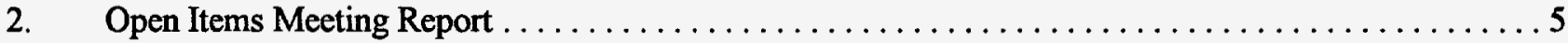

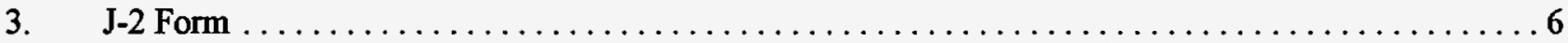

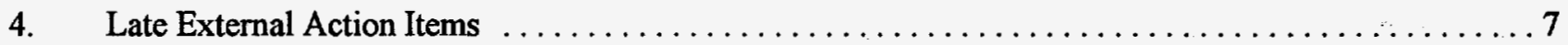

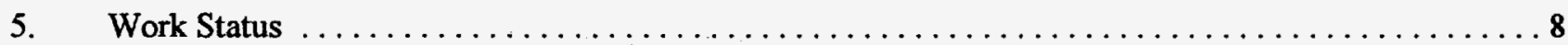

6. External Appraisal/Survey/Audit Flow Chart $\ldots \ldots \ldots \ldots \ldots \ldots \ldots \ldots \ldots \ldots \ldots \ldots \ldots$

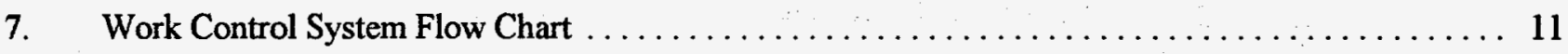

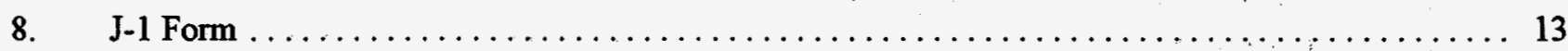

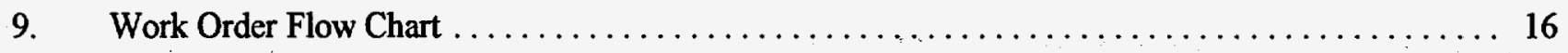

10. Preventive Maintenance \& Instrument Calibration Recall Process Flow Chart . . . . . . . . 18

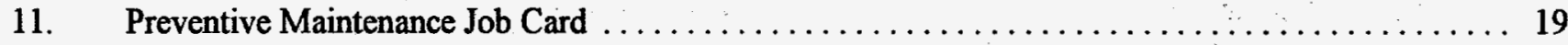

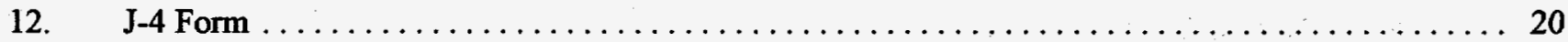

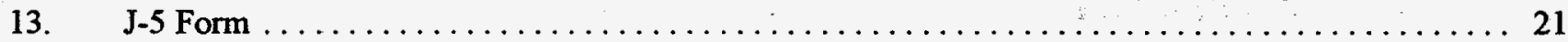

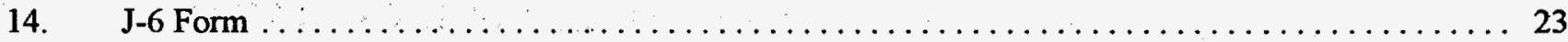

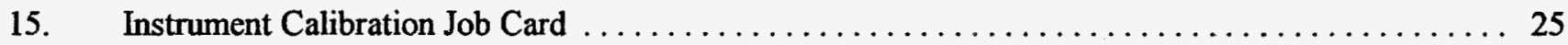

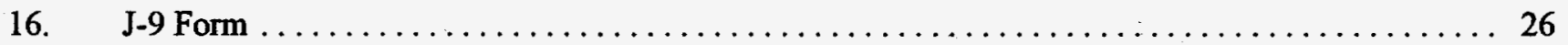

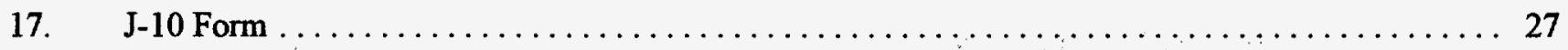

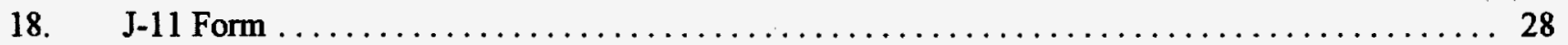

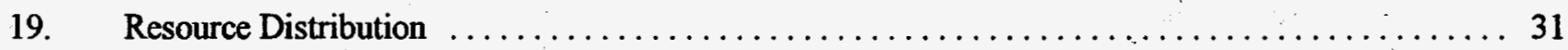

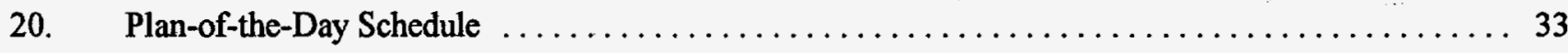




\section{EXECUTIVE SUMMARY}

In the Fall of 1988, the West Valley Nuclear Services Company, Inc. Project Control Department observed an escalating trend of open work items. An Open Items Status Report distributed on a weekly basis identified Internal and External Open Items, but there were no control mechanisms for tracking and closing the open items. It was apparent that the site needed a stronger more structured Open Items control system. The West Valley Nuclear Services Co., Inc. Manager of Construction and Project Administration directed the West Valley Nuclear Services Co., Inc. Manager of Operations Planning to find an effective way to reverse this trend.

The mission of the Manager of Operations Planning was to upgrade the work control procedure, and implement a newer more versatile computerized Work Control System. The new system needed to include a method to effectively track and monitor external open items, as well as an interactive work order tracking system.

The primary objective of the Manager of Operations Planning was to visit other Government Owned Company Operated sites to learn how they worked with Open Items; to examine and question how other Government Owned Company Operated facilities documented, tracked, statused, and completed Open Items in a timely manner; to select the best elements from each of the Government Owned Company Operated facilities; and to develop a high quality, efficient Work Control System for West Valley Nuclear Services Co., Inc.

By taking advantage of Westinghouse's "Savings Through Sharing" concept, the Manager of Operations Planning called upon Government Owned Company Operated managers for help in developing a Work Control System for West Valley Nuclear Services Co., Inc. The Manager of Operations Planning met with several West Valley site managers who had worked at other Government Owned Company Operated sites to determine what sites had effective work control systems. Three sites were selected; Westinghouse Hanford Company, Richland, Washington; Westinghouse Idaho Nuclear Company, Idaho Falls, Idaho; Waste Isolation Division, Carlsbad, New Mexico.

Visits were arranged and meetings were conducted with Work Control Managers at each of the three selected Government Owned Company Operated facilities. The purpose of these meetings was to learn how each managed their Work Control Systems. The discussions focused on how the work control procedures were written, and how to present and implement a work control system. The ideas and suggestions of the Government Owned Company Operated managers demonstrated a willingness and desire to share with West Valley their experiences and knowledge on how to manage an effective Work Control System.

When the Manager of Operations Planning returned to West Valley, he conducted meetings with managers, supervisors, and engineers to review the information, and decide what direction to take in developing their Work Control System. The result of these meetings set the cornerstone of the West Valley Work Control System. The Work Control System was developed to establish, maintain, and utilize a work control database on a mainframe computer to monitor, update, and provide analysis data for external commitment items. This work control database has proved to be an effective means of providing analysis data for maintaining an effective open items tracking system. 


\subsection{INTRODUCTION}

The West Valley Demonstration Project is located on the site of the only commercial nuclear fuel reprocessing facility to have operated in the United States. The plant was operated by Nuclear Fuel Services Company from 1966 to 1972 and reprocessed approximately 640 metric tons of spent nuclear fuel to recover usable uranium and plutonium.

During operation of the facility, approximately 600,000 gallons of liquid, high-level radioactive waste, a by-product of reprocessing, was stored in an underground tank contained within a concrete vault. In 1976, the operator of the facility notified the New York State Energy Research and Development Authority of its intention to cease operations.

In 1980, the West Valley Demonstration Project Act (Public Law 96-368) was signed. The act directs the Department of Energy to: solidify the high-level radioactive waste into a durable, solid form suitable for shipment to an approved federal repository; decontaminate and decommission the tanks and facilities use to perform the Project; and dispose of the low-level and transuranic wastes that result from Project operations.

In 1981, the West Valley Nuclear Services Company, Inc., a fully-owned subsidiary of Westinghouse Electric Corporation, was selected as the prime Project contractor. Department of Energy and West Valley Nuclear Services Co., Inc. assumed operational control of the site in 1982. In 1984, the West Valley Demonstration Project began the test program to convert liquid, high-level radioactive waste into to a durable, borosilicate glass product, and the construction of the Vitrification Facility for high-level waste began. By 1988, the construction and processing of low-level waste activity was well underway. As the site activity intensified, unplanned and emergent work requests increased, which increased the demand for support resources.

It proved to be a difficult challenge to develop an effective Work Control System. At this time, the existing tracking system only identified work items as being "active" or "completed". In many cases the status of work items was virtually unknown, and some work items were never closed. In addition, the facility was subjected to frequent government audits, surveillances and site appraisals. Reports were submitted identifying "Findings" and "Concerns" which resulted in many Action Items that needed to be tracked and monitored. It was of primary importance to the management staff of West Valley Nuclear Services Co., Inc. to demonstrate that it had complete control of all work activities and was able to produce reports and graphs that documented West Valley Demonstration Project's progress. The development of the West Valley Work Control System has enabled management to fully document West Valley Demonstration Project progress and track open items in an efficient, cost-effective way that is easily reportable. 


\subsection{DEVELOPMENT OF THE OPEN ITEMS TRACKING SYSTEM}

The first priority for West Valley Nuclear Services Co., Inc. was to develop a highly efficient Open Items Tracking System, that tracks, monitors, and closes out external commitments in a timely manner. It was decided by West Valley management to first focus on managing external open items, which included audits, surveillances, and appraisals. These Open Items made West Valley highly visible to the Department of Energy and other government agencies/regulatory organizations external to the West Valley Demonstration Project.

The development of an Open Items Tracking System for West Valley required close examination of the other Government Owned Company Operated systems in order to determine the best features of each system and to incorporate features into the West Valley system. Through a comprehensive review of different Government Owned Company Operated systems and procedures, a list of features was identified, including, a unique work control number format that includes information that is valuable to the people performing work tasks; a "wait code" representing five different reasons for delaying the start of work; and a performance measurement system. These and other items were incorporated in the West Valley Open Items Tracking System.

In June of 1989, the development of a program to manage the data in the Work Control System was initiated. The first step for the program analyst was to create a database system to store information. The database was divided into multiple fields for easy access and sorting capability, (see Figure 1). Multiple fields were used in order to sort information and produce reports in a variety of formats requested by managers. Concurrently, the Manager of Planning Operations held meetings with site personnel impacted by the system in order to confirm information needed and to make further enhancements in the data fields. These meetings also gave site personnel the opportunity to directly participate in the decision making process, increasing their sense of ownership in the system and gaining their support for Open Items Tracking System implementation.

The Open Items Tracking System was ready to be tested in August of 1989. It was decided to test and debug the program by tracking the open items of the maintenance department then gradually expand into the other West Valley departments. As the Operations Planning Department was preparing to gather and load maintenance open items data, the Department of Energy initiated a major audit of the West Valley Demonstration Project. After several days the Department of Energy Audit Team submitted their Findings Report to West Valley Nuclear Services Co., Inc. The West Valley management staff in turn submitted the Findings Report to the Work Control Center to use as an Open Items Tracking System test module.

\subsection{External Audits/Appraisals/Surveillance}

External regulatory organizations including, the Department of Energy, the Nuclear Regulatory Compliance, and the Environmental Protection Agency routinely conduct audits, appraisals, and surveillances at the West Valley Demonstration Project. Immediately following a West Valley Demonstration Project site inspection, an external regulatory organization will submit a report to the Department of Energy West Valley Project Office. The report identifies "Findings" that describe the discrepancies or problems that were observed during the audit, appraisal, or surveillance. After submittal to the West Valley Project Office, the report is forwarded to West Valley Nuclear Services Co., Inc. for resolution.

A "Findings" report is given to a Responsible Action Manager to resolve the issues identified in the report, and Action Managers are assigned the task of dividing the Findings into individual Action Items. Each Action Manager is required to submit an action plan to the Responsible Action Manager describing the tasks that will be performed to close their Action Items. The Responsible Action Manager in turn develops a plan describing the Action Item responses, indicating completion dates, and identifying the Action Item Managers. An Action Plan is 


\section{OPEN ITEMS STATUS}

\begin{tabular}{|c|c|c|c|c|c|c|}
\hline WAS & $\begin{array}{c}\text { WOAK CONTAOL } \\
\text { NUMBER }\end{array}$ & $\begin{array}{l}\text { DOCUMENT } \\
\text { REF, NO. }\end{array}$ & PALOAITY & DESCRIPTION & $\begin{array}{l}\text { EQUIPMENT } \\
\text { LDENTIFICATION }\end{array}$ & LOCATION \\
\hline 105260023 & CSS-8900100-1/Wo & CM88129.1 & 2 & $\begin{array}{l}\text { INSTALL NEW } \\
\text { FILLER NOZZLE }\end{array}$ & $070 \mathrm{D} 015$ & 0114 \\
\hline
\end{tabular}

$\begin{array}{lcccc}\text { DATE } & \text { ACTION } & \text { STAFF } & \text { PERFORMANCE } \\ \text { LISTED } & \text { OBIGINATOR } & \begin{array}{c}\text { MGR/COG } \\ \text { MGR }\end{array} & \text { CODE } \\ 1 / 10 / 89 & \text { HUMMEL } & \text { CWYNAR } & \text { GESSNER } & \text { AO2 }\end{array}$

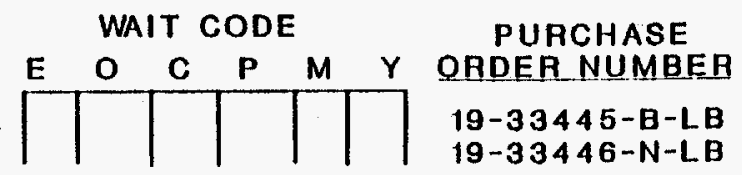

\begin{tabular}{|c|c|c|c|c|c|c|}
\hline WORK STATUS & MCD & $\begin{array}{l}\text { CORRECTIVE } \\
\text { MAINTENANCE }\end{array}$ & $\begin{array}{l}\text { PLAN } \\
\text { START }\end{array}$ & $\begin{array}{l}\text { REQD } \\
\text { EINISH }\end{array}$ & $\begin{array}{l}\text { FRCST } \\
\text { START }\end{array}$ & $\begin{array}{l}\text { FRCST } \\
\text { EINISH }\end{array}$ \\
\hline WIP & $2 / 20 / 89$ & $\gamma$ & $1 / 15 / 89$ & $2 / 25 / 89$ & $2 / 25 / 89 A$ & $2 / 25 / 89$ \\
\hline $\begin{array}{l}\text { SUPPORT } \\
\text { REQD }\end{array}$ & $\begin{array}{l}\text { EST } \\
\text { MH }\end{array}$ & $\begin{array}{l}\text { AES } \\
\text { IYPE }\end{array}$ & $\begin{array}{c}\text { SUPPORT } \\
\text { MGR }\end{array}$ & & COMMENTS & \\
\hline $\begin{array}{l}\text { RNSA } \\
\text { MAINT } \\
\text { QUAS }\end{array}$ & $\begin{array}{r}2 \\
12 \\
1\end{array}$ & $\begin{array}{l}\text { ENGR } \\
\text { TECH } \\
\text { TECH }\end{array}$ & $\begin{array}{l}\text { HARWARD } \\
\text { KEEL } \\
\text { SHUGARS }\end{array}$ & & & \\
\hline
\end{tabular}

Figure 1. Open Items Status 
then submitted to the West Valley Project Office for review and approval, and to the Work Control Center to be entered into the Open Items Tracking System.

The Action Item Managers perform the required tasks as described in the Action Plan. They report the status of the Action Items at a weekly Open Items Tracking System Meeting. An open items report that describes the open items and their current status is distributed weekly by the Work Control Center to the West Valley Project Office, West Valley Nuclear Services Co., Inc. Staff managers, and site managers who are impacted by the Action Plan, (see Figure 2). When all the Findings/Action Items have been completed, the Responsible Action Manager summarizes the Findings and sends a Final Summary Report to the Work Control Center for final disposition of the Action Items. The Work Control Center forwards the completed package to the West Valley Project Office for review and concurrence. Following West Valley Project Office concurrence, the original report is closed out, removed from the Open Items Tracking System, and archived into a History database for future reference.

\subsection{Commitment Item Form (J-2)}

When the Action Plan is initially submitted for processing to the Work Control Center, a J-2 Form that identifies each Action Item is forwarded to specific Action Managers for completion. The Action Managers review the Action Item descriptions, set the action item priorities, establish the planned start dates, and sign the forms confirming responsibility, (see Figure 3 ).

The required finish dates are preset by the external regulators and cannot be changed. The Action Manager sets the planned start date and the forecasted completion date. These dates can be adjusted as necessary. If the forecasted date goes beyond the required date, the Action Items appear on the Open Items Late List, (see Figure 4).

Weekly Status Meetings are held to report the current status of Open Items (see Figure 5). These meetings provide an opportunity to identify potential problem areas that could impact the planned completion dates. Status meetings are attended by the Action Managers and Staff Managers who are responsible for the Open Items to be discussed. The Action Manager performs and completes the required task as described on the J-2 Form and signs-off the J-2 Form indicating the required action was completed. The J-2 Form is then returned to the Work Control Center, along with any necessary supporting documentation.

\subsection{Final Closeout}

When all the Action Items identified in a Finding have been completed, the J-2 Forms and supporting documentation are forwarded to the West Valley Project Office as a complete package for review and concurrence. The West Valley Project Office is required to sign the J-2 Forms, thus indicating the open action items have been completed to their satisfaction. The complete package is then returned to the Work Control Center to close-out the action items/finding from Open Items Tracking System and is then forwarded to Records Management for storage and retrieval, (see Figure 6). 


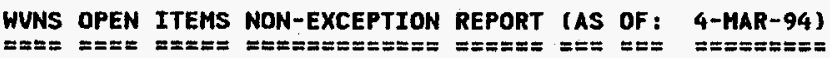

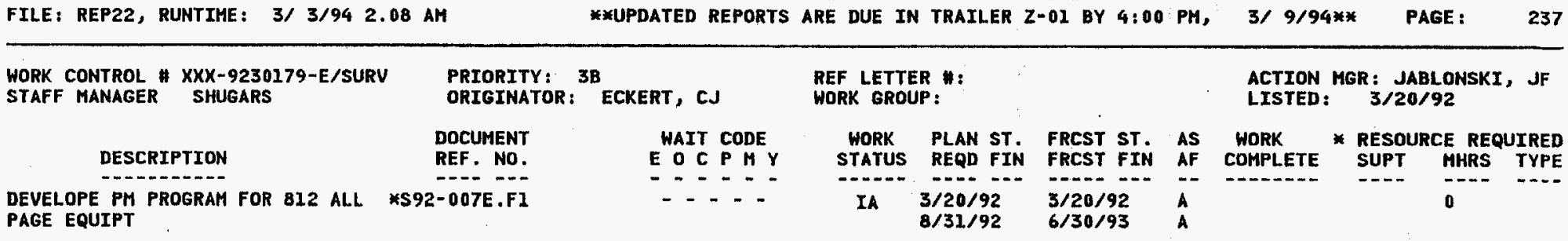

DEVELOPE PM PROGRAM FOR B12 ALL *S92-007E.F

COM: NON-CONCURRED BY DOE - J-2 AT J JABLONSKI 8/4/93

WORK COMPLETE, JABLONSKI WILL CLOSE

ACTIONS: DEVELOPE PM PROGRAM FOR 812 ALL PAGE EQUIPT

PRIORITY: 3B
ORIGINATOR: ECKERT, C.J REF LETTER " :

ACTYON MGR: JABL.ONSKI, JF

DOCUMENT

REF. MO.

DESCRIPTION

WAIT CODE

E O C P M Y

$\ldots$

$\begin{array}{lll}\text { HORK } & \text { PLAN ST. FRCST ST. AS } & \text { WORK } \\ \text { STATUS REQD FIN } & \text { FRCST FIN AF COMPLETE } & \text { RESOURCE REQUTRED } \\ \text { SUPT MHRS TYPE }\end{array}$ STATS REQD FIN FRCST FIN AF COMPLETE SUPT MHRS TYPE WIP $\begin{array}{lll}3 / 20 / 92 & 3 / 20 / 92 & \text { A } \\ 7 / 14 / 92 & 7 / 14 / 92 & \text { A }\end{array}$ WTLL BE INSTALLED IN ALL OFC

COM: NON-CONCURRED BY DOE - J-2 AT JABLONSKI 8/4/93

REPORTED CLOSED ON :14-JUL-92 BY JF JABLONSKI PER LIGHTS INSTALLED

ACTIONS: INSTALL SPEAKER INDICATOR LIGHTS, WILL BE INSTALLED IN ALL OFC AREAS

WORK CONTROL \# XXX-9230181-E/SURV

STAFF MANAGER SHUGARS

\section{DESCRIPTION} PERHANENTLY INSTALL SPEAKERS IN KS92-007E.F3
OFC AREAS

COM: NON-CONCURRED BY DOE - J-2 AT JABLONSKI 8/4/93

ACTIONS: PERMANENTLY INSTALL SPEAKERS IN OFC AREAS
REF LETTER \#:
HORK GROUP:

ACTION MGR: JABLONSKI, JF

ORIORITY: 3 :

DOCUMENT WAIT CODE

E O C P M Y

- - . - -

LISTED: $\quad 3 / 20 / 92$

WORK PLAN ST. FRCST ST. AS WORK * RESOURCE REQUIRED STATUS REQD FIN FRCST FIN AF COMPLETE SUPT MHRS TYPE $\begin{array}{lll}3 / 20 / 92 & 3 / 20 / 92 & A \\ 6 / 30 / 92 & 6 / 30 / 92 & A\end{array}$

$6 / 30 / 92$ .

$$
\text { 6/30/92 }
$$


Not for Shop Order or Work Order

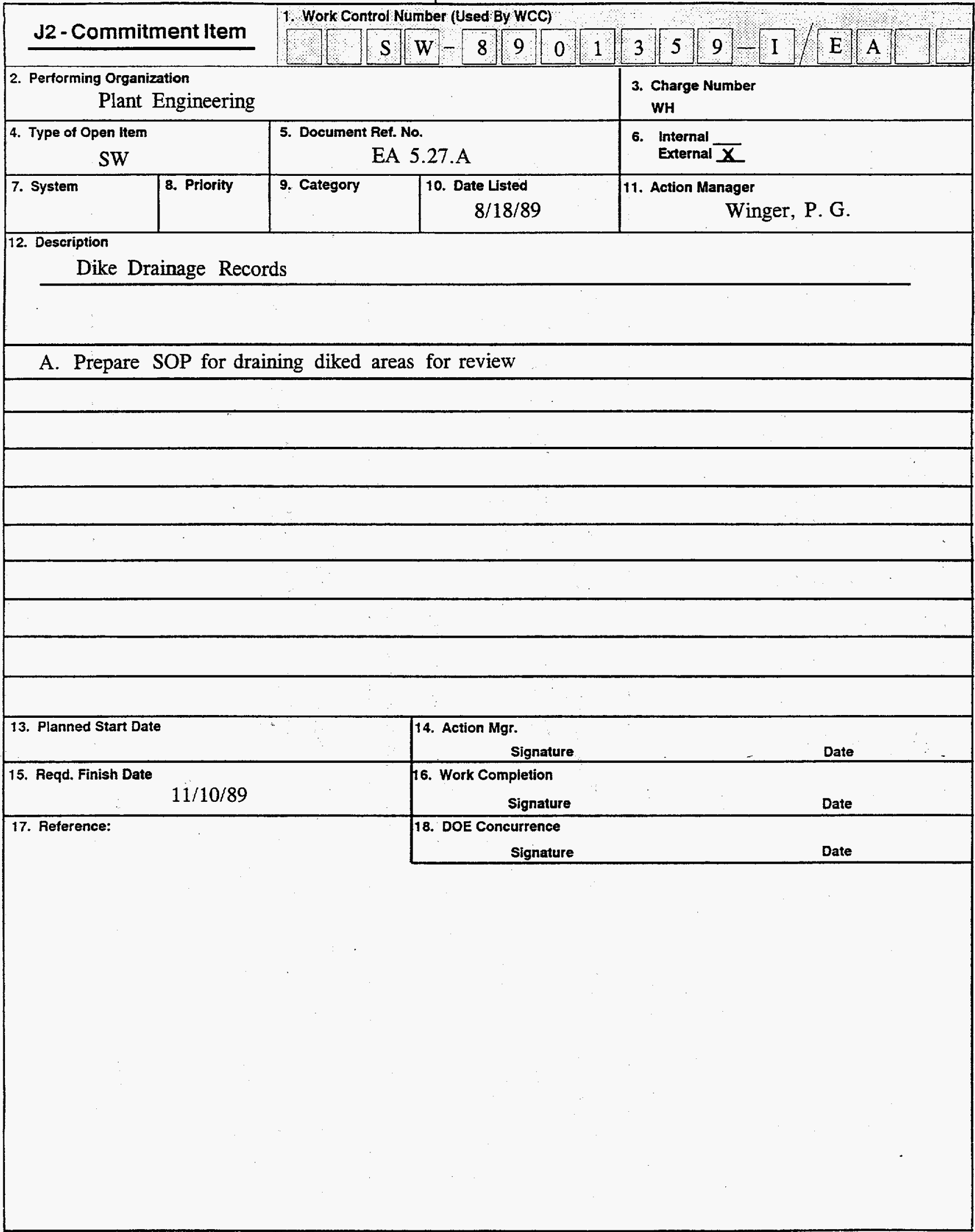




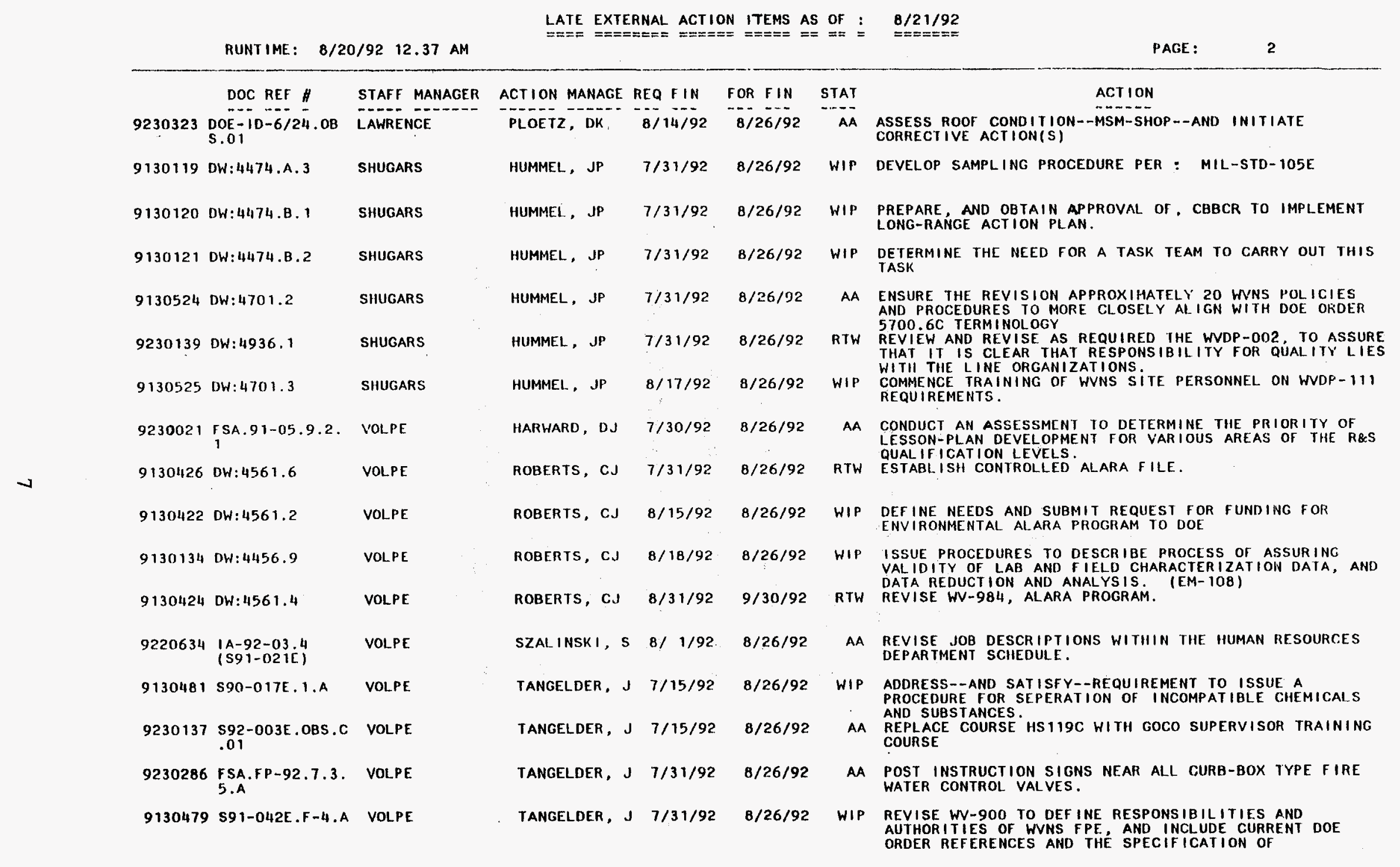

Figure 4. Late External Action Items 


\title{
WORK STATUS
}

\author{
AA - AWAITING APPROVAL \\ IA - INITIATED AND APPROVED \\ OH - ON HOLD \\ RTW - READY TO WORK
}

WIP - WORK IN PROGRESS

CAS - COMPLETE AWAITING SIGN-OFF

C - COMPLETE

CA - CANCELLED

CDOE - COMPLETE DEPT. OF ENERGY

Figure 5. Work Status 


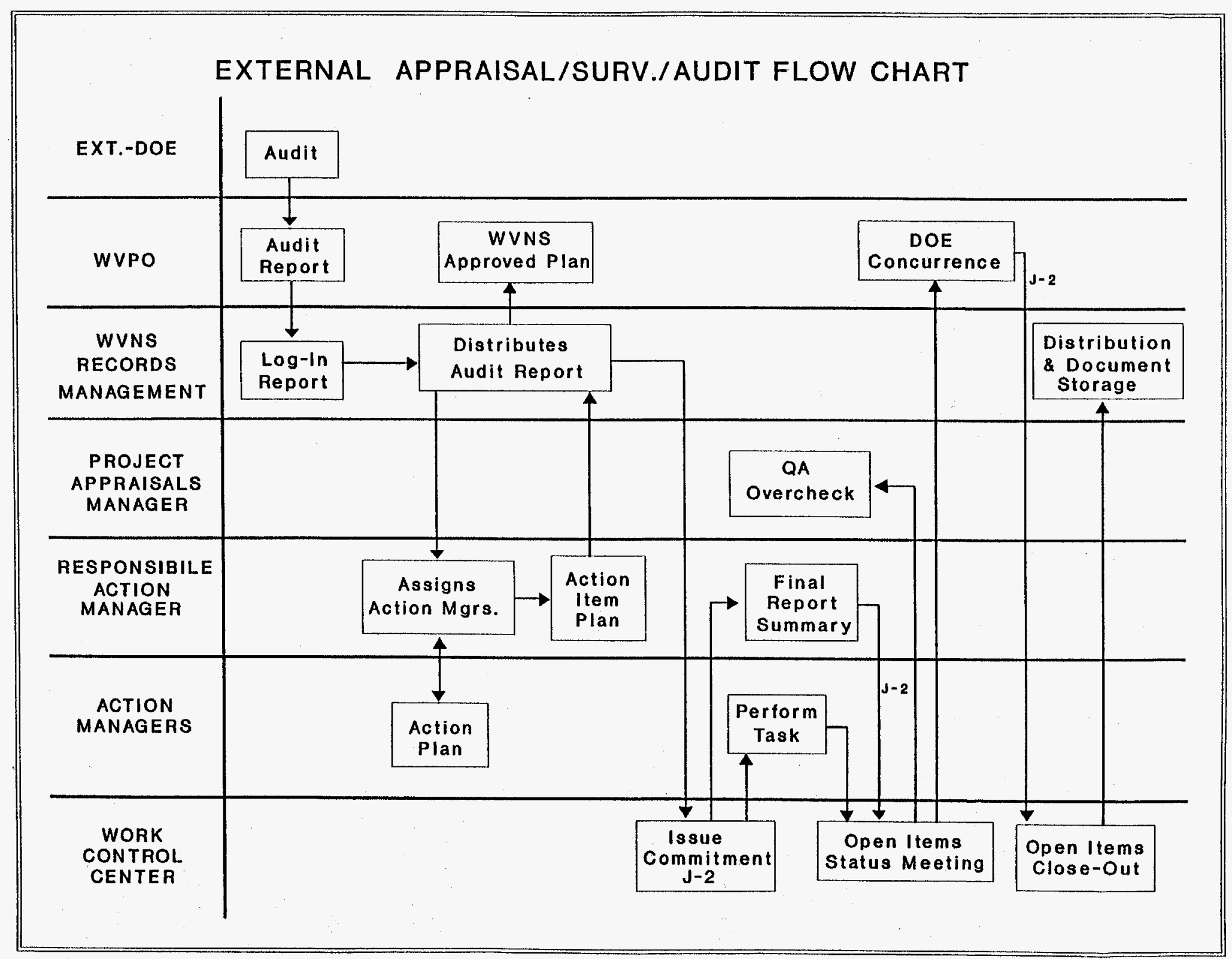

Figure 6. External Appraisal/Survey/Audit Flow Chart 


\subsection{WORK ORDER CONTROL SYSTEM}

The challenge to develop a highly efficient Work Order Control System to control the site demand for unscheduled and non-routine work requests required the support of all levels of management. Meetings were held with upper level managers to identify inherent weaknesses of the existing work order system, and to discuss the advantages of a stronger, more efficient system. It was important that upper level managers made clear the need to support this effort to their line managers as the success of this program largely depended on the people who were going to be impacted by the system.

Meetings were also held with site personnel to get their input and suggestions. We've all heard the expression "if I had my druthers, I would do things differently" - an opportunity to express their concerns and discuss different approaches on how best to manage unscheduled, non-routine work requests. Several meetings were conducted, utilizing a "brainstorm" approach to review the old system and analyze other Government Owned Company Operated systems.

As a result of these meetings, the Open Items Tracking System was expanded to implement site-wide work order control as well as to manage external commitment items. Site-wide work order control involves the issuance and tracking of Work Orders and Shop Orders to ensure timely close-out of open items.

\subsection{Requirements}

The Work Control System is the administrative control of Work Orders, the process required to implement the work activities identified in Work Orders that are prepared by the facility engineers. The Work Order Control System Flow Chart (Figure 7) shows the sequence of events that are followed from initiation of a work request to post work review.

\subsubsection{Work Item Identification}

The primary method of initiating a work item is to complete a Work Authorization Form (J-1). The J-1 Form is used to identify any work item(s) necessary to maintain or modify the West Valley Demonstration Project.

The work order originator requesting the work to be performed submits an approved J-1 Form, which is filled-out in accordance with all relevant West Valley Nuclear Services Co., Inc. guidelines and procedures. The originator is responsible for preparing approved work instructions in sufficient enough detail to provide the responsible work group with a clear understanding of the task to be performed, and to ensure personnel safety and equipment protection, (see Figure 8).

\subsubsection{Work Package Preparation}

The primary requirements for a work package consist of an identification of skilled crafts, the estimation of manhours required to perform the work, approved work instructions, preparation of permits, and obtaining required approvals. 


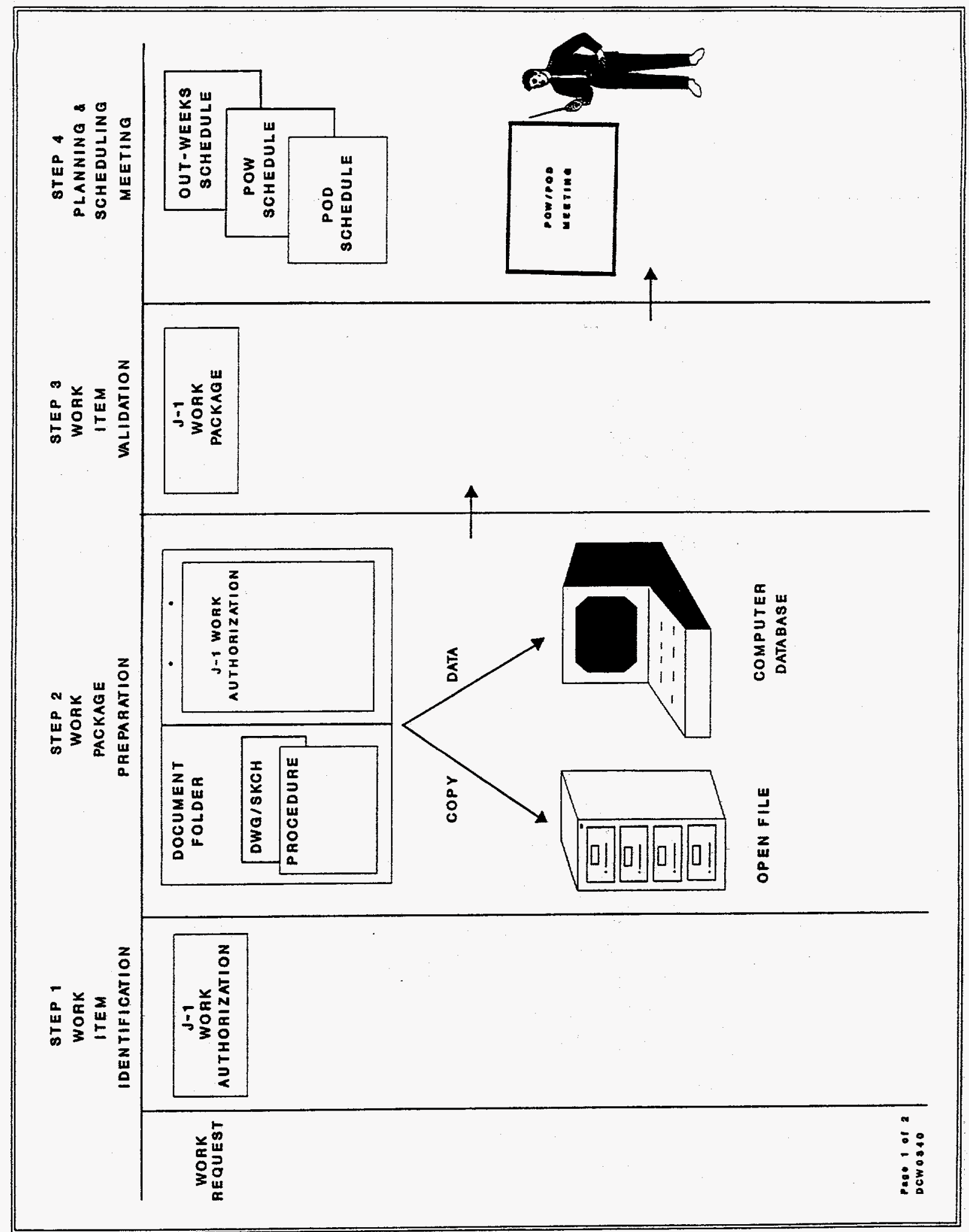

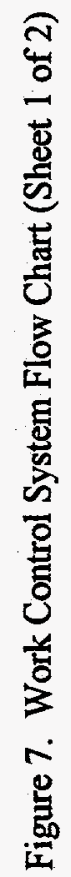




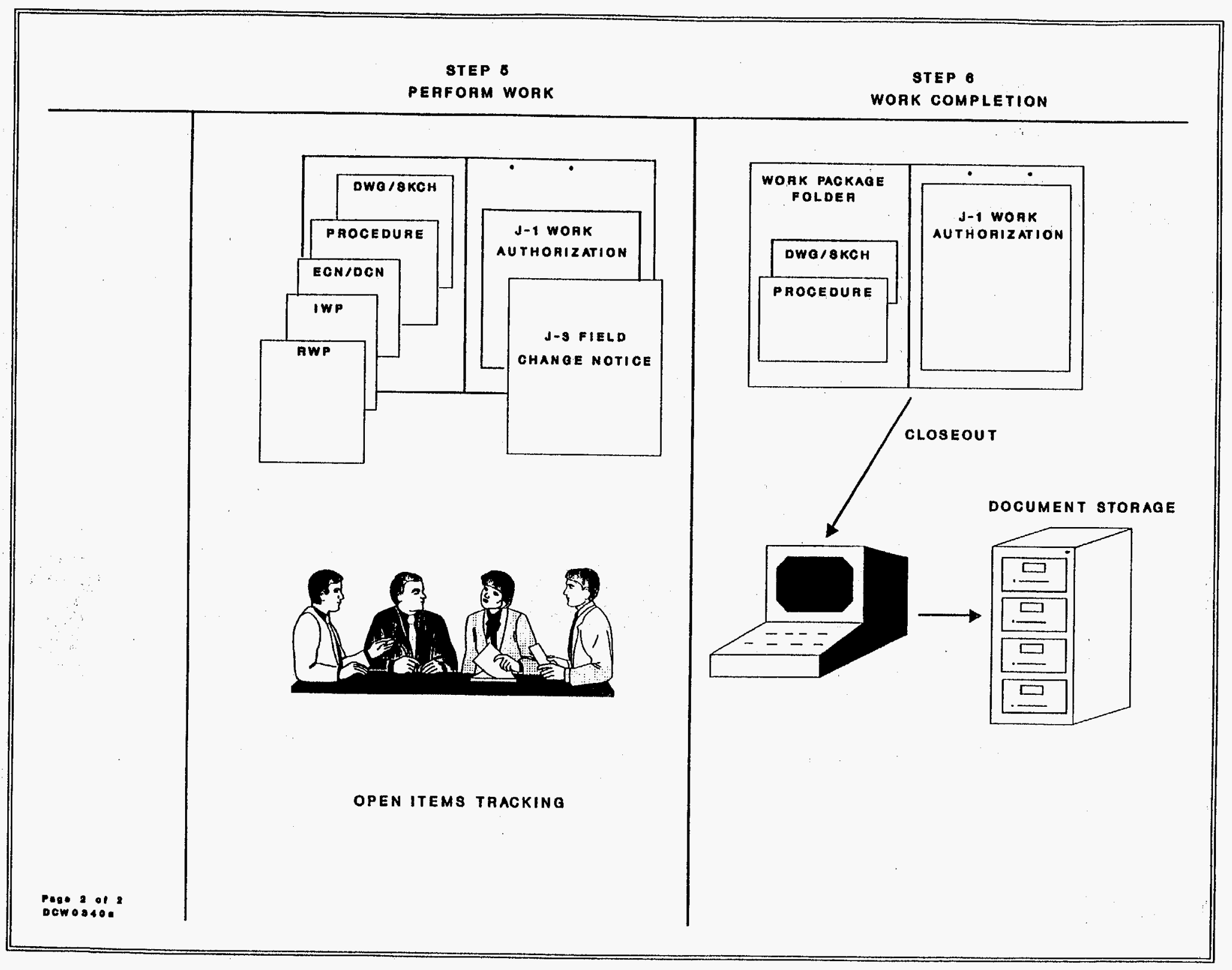

Figure 7. Work Control System Flow Chart (Sheet 2 of 2) 
Work Orders \& Shop Orders Only (Others Use J-2)

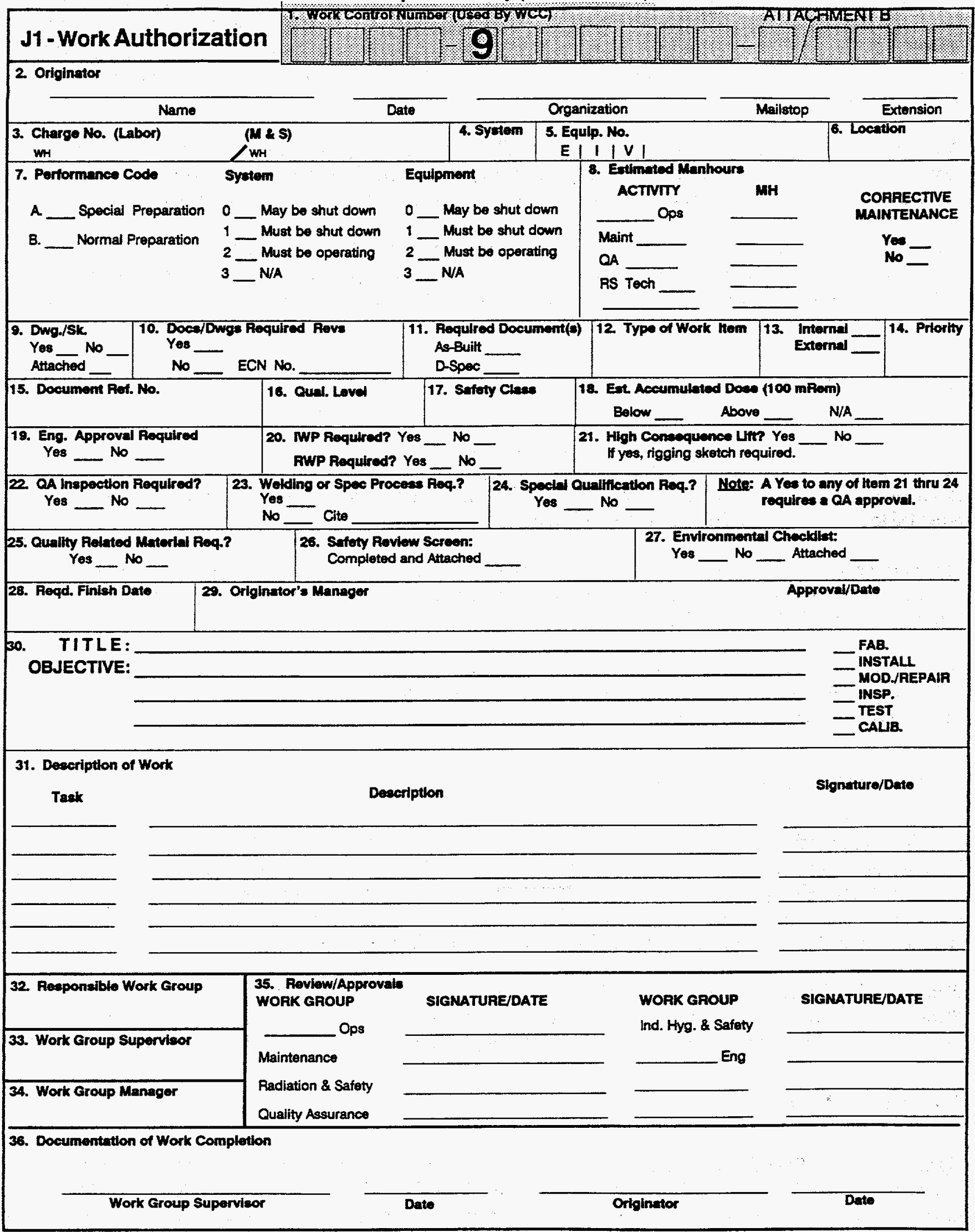

WV-1080, Rev. 7

WV:0000426.RM

Figure 8. J-1 Form 
A work package is prepared by placing a completed J-1 Form and related documents into a Work Package Folder. The Work Package Folder is then routed to a Work Review Group for approval. When all the required approval signatures have been obtained, the Work Package Folder is forwarded to the Responsible Work Group assigned the work task. Prior to starting the work, an Industrial Work Permit and/or a Radiation Work Permit must be added to the folder if required.

Work package instructions must provide sufficient detail to ensure proper performance of the work. They may consist of simple instructions or detailed descriptions of the work scope. Reference documents include welding procedures, deviation from standard work practices, permits, operation procedures, and/or test specifications.

Special personnel qualifications, and other prerequisites, are identified and accomplished before work starts. These may include items such as necessary prefabrication, tagouts, electrical and mechanical system lineup. In addition, careful consideration is given to the various permits and special procedures that are required prior to and during the work process

\subsubsection{Work Package Validation}

The Work Review Group identified on the J-1 Form, is cognizant of the safety, operational, and environmental concerns of the facility and is required to review the work package for correctness. It is their responsibility to review and approve the work request before it is issued to the Work Group, and to ensure sufficient information is provided to clearly describe the work to be performed.

The Work Priority indicated on the J-1 Form is a four level numeric system $(1,2,3, \& 4)$ that denotes the level of importance relative to personnel safety and equipment protection. The priority as determined by the originator is confirmed by the Work Review Group.

Work Package Approval - A work request must be approved before it can be implemented. Necessary approvals include approval by the originator's manager, Maintenance group, the Operations Manager, Radiation \& Safety, and Quality Assurance, (if required).

\subsection{Work Planning \& Scheduling}

The planning and scheduling of Work Orders is administered through a hierarchy of plans and schedules from a Long-Range Plan down to a detailed Plan-of-the-Day schedule. Schedules which project several weeks forward define the West Valley programmatic missions, while near-term schedules of less than one week show the detailed activities necessary to maintain and operate the facility. The planning and scheduling of Work Orders are controlled through a series of weekly and daily planning and scheduling meetings.

Plan-of-the-Week meetings are held every Friday to review and plan the upcoming week's work requirements. A Plan-of-the-Day meeting is held every afternoon to review the work planned for the next day. The primary function of conducting these meetings is to ensure that support resources are available for the next day's activities.

\subsection{Perform Work}

Upon completion of the Work Review Group approval, and obtaining the necessary work permits, the Work Package is ready to be worked. The assigned Responsible Work Group has the responsibility to perform the tasks as directed by procedure. It is their responsibility to ensure all completion signatures are on the Work 
Authorization Form (J-1), indicating that the work has been completed and performed in accordance to the work instructions.

A Field Change Form (J-3) is used to change work instruction when unforeseen circumstances prevent the performance of work tasks as defined in the work package. The Responsible Work Group or originator initiates the action to change the work instructions. Changes must be approved by the same group that approved the original Work Order.

\subsection{Work Completion}

When the work tasks have been completed, the Responsible Work Group reviews the Work Package to ensure that all required work activities were performed, all appropriate signatures obtained, and the acceptance criteria met. The Work Group Supervisor's signature certifies that all the documentation for the work group has been completed. The work order is then returned to the Work Control Center for final review and sign-off.

Before a work order can be closed, the originator must review and evaluate and sign-off that the work has been satisfactorily completed. The Work Control Center then has the responsibility to review the work order to check if all the work tasks have been signed-off as completed. When all the sign-off signatures have been obtained, the Work Control Center closes-out the Work Package in the Open Items Tracking System database, and forwards the completed Work Package to Records Management for storage and retrieval (see Figure 9). 


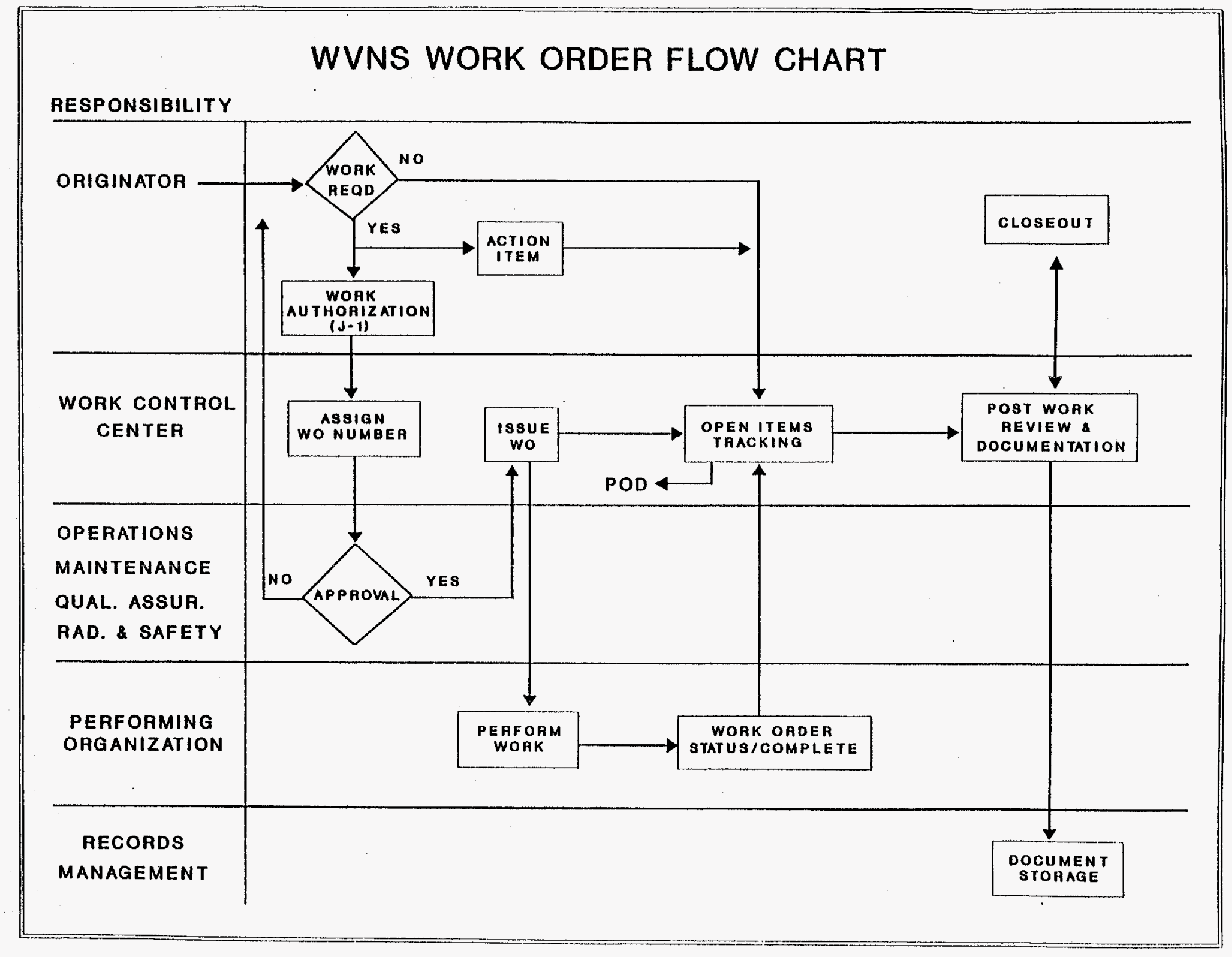

Figure 9. Work Order Flow Chart 


\subsection{PREVENTIVE MAINTENANCE \& INSTRUMENT CALIBRATION RECALL SYSTEM}

This section describes the administration of the Preventive Maintenance \& Instrument Calibration Recall system that monitors requirements, responsibilities, and procedures. The Preventive Maintenance \& Instrument Calibration Recall database is a sub-system of the Work Control System, and is an integral function of the administrative process.

A Responsible Systems Engineering Group determines if a component is required to be tracked as a Preventive Maintenance \& Instrument Calibration Recall item. The appropriate forms describing the necessary requirements to perform these tasks are filled out and submitted to the Responsible Work Group for review and approval. The information that has been indicated on the forms are subsequently loaded into the database by the Work Control Center. The Work Control Center maintains the data and issues the Preventive Maintenance \& Instrument Calibration Recall Job Cards when the work is to be performed.

The Preventive Maintenance \& Instrument Calibration Recall Job Card describes the work tasks in detail, and a historical database is updated each time a Preventive Maintenance \& Instrument Calibration Recall is performed. In addition, the Work Control Center issues a monthly status report to the work groups that have overdue activities, (see Figure 10).

\subsection{Preventive Maintenance}

Preventive Maintenance is the activity that is performed at established frequencies to ensure a trouble free operation of a facility or component. Preventive Maintenance includes periodic activities to prevent equipment breakdown such as inspections, vibration analysis, oil analysis, instrument surveillance, and planned maintenance as dictated by periodic maintenance results, vendor recommendation, or experience.

A Preventive Maintenance Job Card, issued by the Work Control Center, is a computer generated document that identifies periodic mechanical, electrical, or instrumentation maintenance, and contains information required to perform the required Preventive Maintenance activity, including a step-by-step procedure. The Job Card also serves as the official work authorization document that is used by the mechanics at the job location, (see Figure 11).

\subsubsection{Responsibilities}

Cognizant Engineers are responsible for determining if equipment requires Preventive Maintenance. They are responsible for completing the Equipment Information Sheets (J-4 form) and the Preventive Maintenance Data Sheets (J-5 form), requesting Preventive Maintenance support, and furnishing technical manuals and operating procedures to the Responsible Work Groups, (see Figures 12 and 13).

The Work Control Center is responsible for issuing Job Cards, tracking the Preventive Maintenance status of equipment, controlling the database to ensure timely Preventive Maintenance recall, and to provide traceability.

The Preventive Maintenance database is used to manage the information, maintain an index of components, provide forecasts of components due for Preventive Maintenance activity, maintain a record of preventive maintenance performed, and store component data history. The Responsible Work Group performs the Preventive Maintenance tasks as described by the Job Card, and fills out the Job Card when the work is completed. 


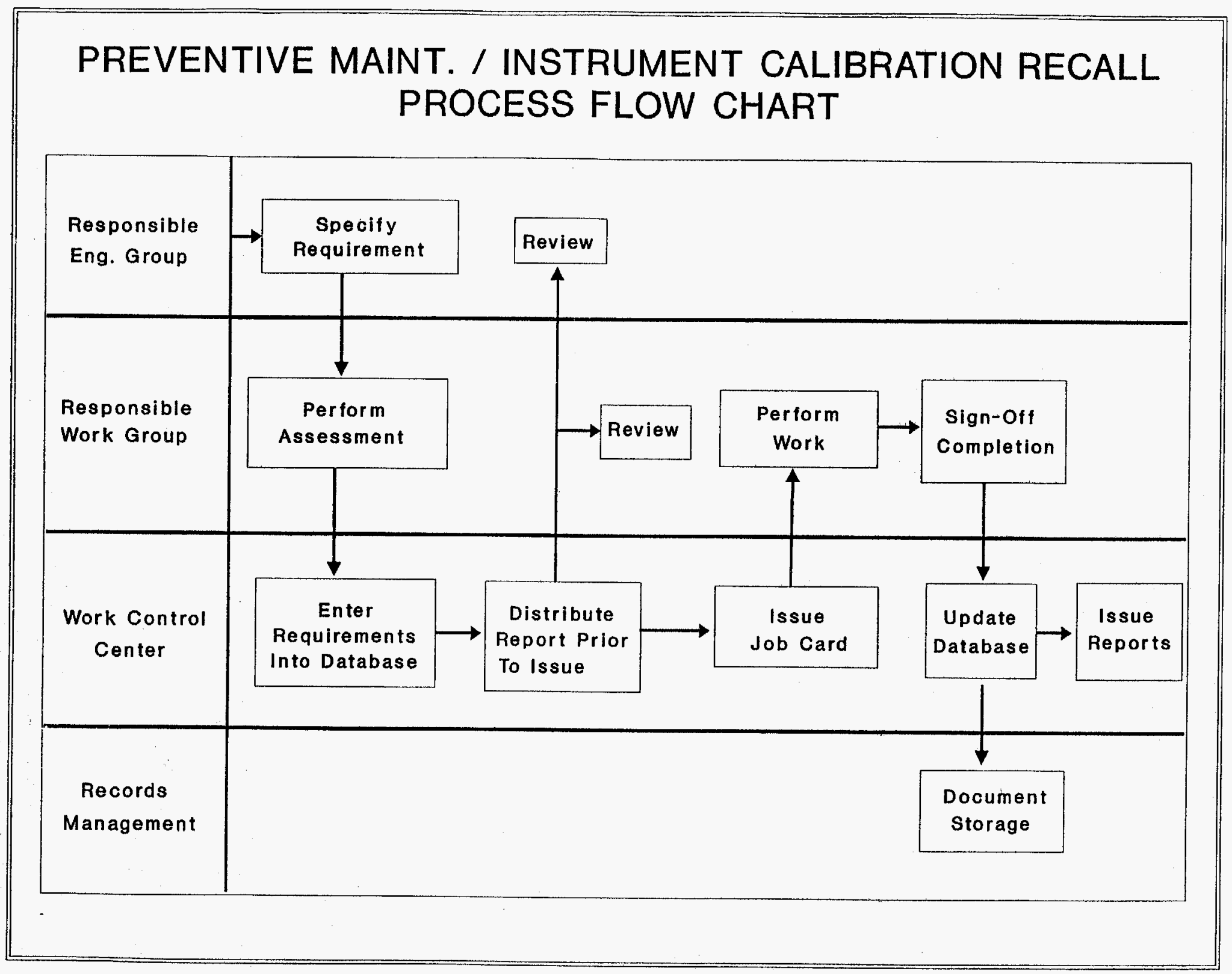

Figure 10. Preventive Maintenance and Instrument Calibration Recall Process Flow Chart 
$\underset{P M}{\operatorname{PJOB} \text { CARD FOR: } \quad 31 \mathrm{G}-2 / 1 / 2}$

WVNS PM JOB CARD GENERATOR RUNTIME: $6 / 11 / 91$ 8.10 AM $==========0======$

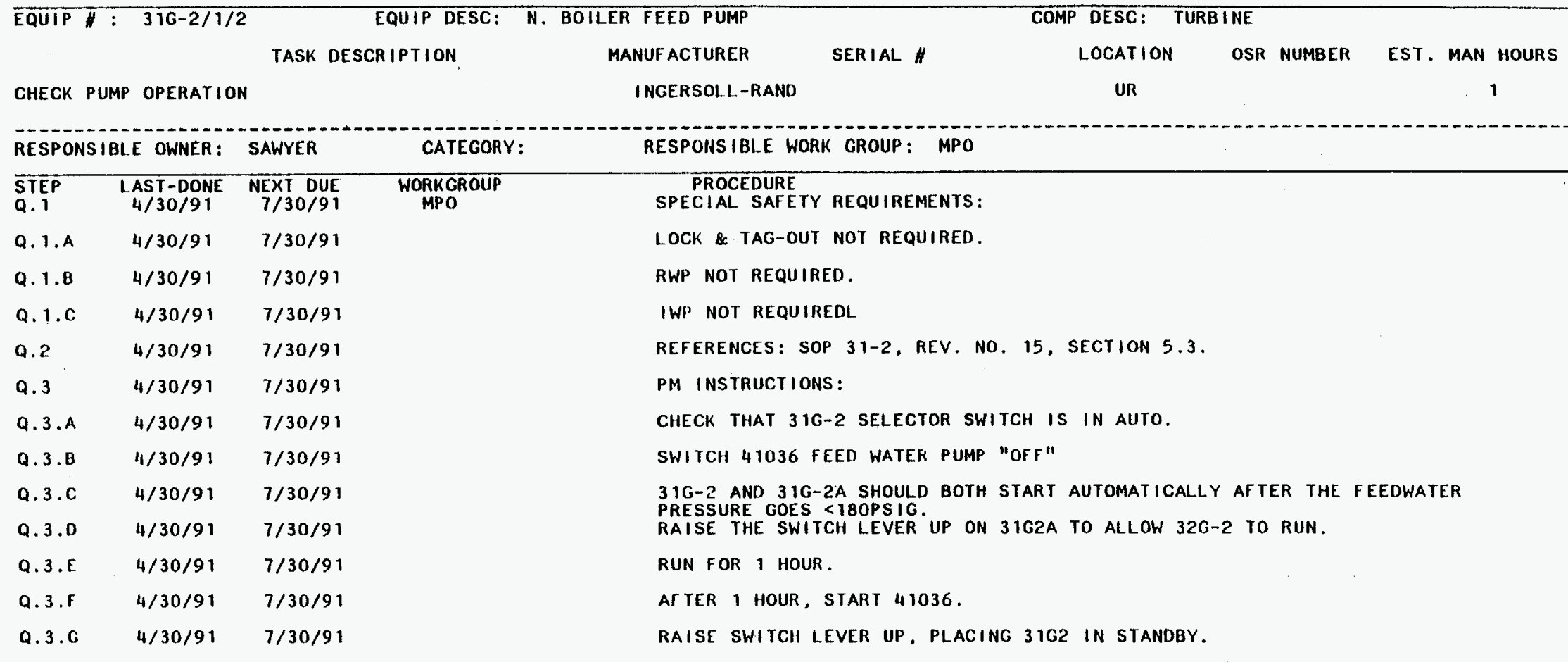

COMMENTS-DACTIONS TAKEN, OR PROBLEMS IOENTIFIED: TYPE: 1821

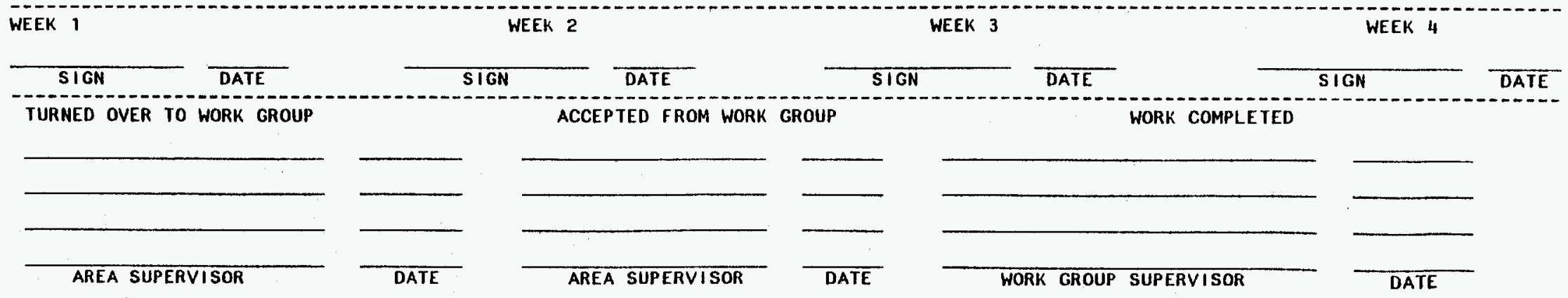

Figure 11. Preventive Maintenance Job Card 


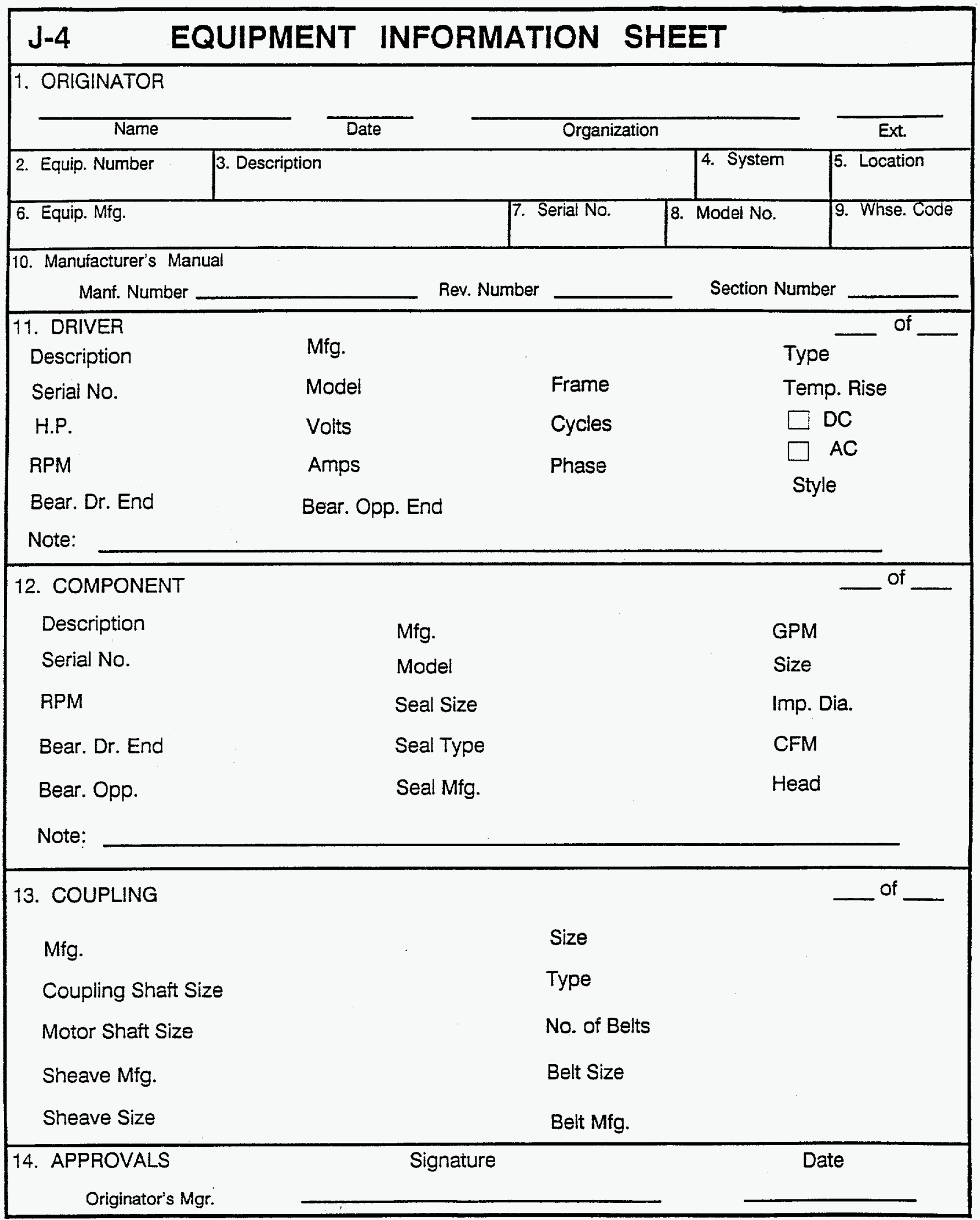

WV-1089, Rev. 2

Figure 12. J-4 Form 


\section{J-5 PREVENTIVE MAINTENANCE DATA SHEET}

1. Originator

\begin{tabular}{|l|l|l|l|}
\hline \multicolumn{2}{|c}{ Name } & 3. Description & \multicolumn{2}{c}{ Organization } \\
\hline 2. Equip. Number & 5. Category & 6. Frequency & 7. Due Date \\
\hline 4. OSR/TR-Surveillance No. & 9. System & 10. Location & 11. Rad. Area \\
\hline 8. Responsible Work Group & & & Est. Manhours \\
\hline
\end{tabular}

13. Procedure

1. Special Safety Requirement:

1a. Lock \& Tag-Out Required: Yes

1b. RWP Required: Yes No

1c. IWP Required: Yes No No

2. References:

Rev. No.

Section

2a. Manf. Manual No.

3. PM Instructions:

14. Approvals

Operations Mgr.

Work Group Mgr.

Radiation \& Safety

Quality Assurance

WV-1090, Rev. 2

Figure 13. J-5 Form 


\subsubsection{Procedure}

The Cognizant Systems Engineering Groups are responsible for initiating the Equipment Information Sheet (J-4), and Preventive Maintenance Data Sheet (J-5) that identify the Preventive Maintenance requirements for new equipment, or to modify existing equipment. The Responsible Work Groups review the J-4 and J-5 forms for new equipment to concur on the Preventive Maintenance requirements. The Work Control Center enters the regular routine maintenance work in the computer database which outputs Preventive Maintenance Job Cards that describe the tasks to be performed.

Two weeks prior to the first of each month, a list of upcoming Preventive Maintenance work items is sent to the Responsible Engineering Groups and Responsible Work Groups to be reviewed and used for schedule planning. One week prior to the first of the month, Job Cards are issued to the Responsible Work Groups. Preventive Maintenance work is then performed in accordance to procedures described on the Job Cards. Work Group Supervisors sign the Job Cards when the work tasks are completed. The signed-off Job Cards are then forwarded to the Work Control Center to be processed and recorded into the history database. All completed Job Cards are then transferred to Records Management for storage and retrieval.

\subsubsection{Temporary Waiver of Preventive Maintenance Procedures}

All Preventive Maintenance is performed as scheduled unless a temporary waiver has been approved by the Work Group Supervisor and Area Supervisor. Preventive Maintenance procedures cannot be waived two consecutive times unless there is justification for not performing the work more that one frequency interval, in which case a request for suspension is submitted, (see Figure 14).

All safety related equipment in which a specific Preventive Maintenance activity has been identified in the Safety Analysis Report is a category I item. Preventive Maintenance requirements are performed as scheduled for these items. If the Preventive Maintenance work task cannot be performed, then an Occurrence Report or a Critique is prepared concerning nonperformance of the scheduled Preventive Maintenance activity.

\subsubsection{Cancellation or Suspension}

Request to cancel or suspend Preventive Maintenance work tasks are accomplished by filling out a J-6 Form. This will prevent the Job Card from being issued, and the affected item will not appear on another job card or schedule until a reactivation date is entered into the database. In general, Preventive Maintenance is performed as scheduled. Justification for suspension or cancellation is limited to the following conditions:

- Equipment is out of service for repair and as a result, performance of the Preventive Maintenance work is not possible.

- Equipment is in use; to perform a Preventive Maintenance would require a process shutdown.

- Equipment is located in an inaccessible portion of the plant (i.e., cells, high radiation areas, etc.) that prevent a Preventive Maintenance work task from being performed until personnel access is restored.

- Equipment has been removed from service permanently or for an extended period of time. 


\section{J-6 PM Cancellation, Suspension, Reactivation}

\section{Originator}

Name

Date

Organization

Extension

2. REQUIRED ACTION

$\square$ Cancel

Suspend

Reactivate

\begin{tabular}{|l|l|l|}
\hline Equip. No. & Effective Date & Justification \\
\hline & & \\
\hline & & \\
\hline & & \\
\hline & & \\
\hline & & \\
\hline & & \\
\hline & & \\
\hline & & \\
\hline & & \\
\hline
\end{tabular}

3. COMMENTS

4. APPROVALS

Signature

Date

Originator's Mgr.

Operations Mgr.

Work Group Mgr.

WV-1092, Rev. 1

Figure 14. J-6 Form 


\subsubsection{Revision and Change Control}

Managers of Systems Engineering, Operations, or the Responsible Work Group may request changes to the Preventive Maintenance procedures. Preventive Maintenance procedures are modified by a Field Change (J-3 form), and approved by the same organization who approved the original procedure.

\subsubsection{Equipment History Card}

A standard Equipment History Card is maintained by the Work Control Center. Each time work is performed on a piece of equipment, Preventive Maintenance information is recorded on the Equipment History Card. This information consists of equipment component numbers, equipment descriptions, dates, work descriptions, mechanic and manhours used to complete the work.

\subsection{Instrument Calibration Recall}

Instrument calibration is the comparison of a measurement standard of known traceable accuracy with another standard to detect, correlate, report, or eliminate by adjustment, within the required accuracy of the instrument being compared. Administration of the Instrument Calibration Recall system, includes tracking, monitoring, and responsibility for maintaining Instrument Calibration Recall requirements.

An Instrument Calibration Job Card is a computer generated document that is used by the Work Control Center to control work relating to calibrations. The Job Cards provide specific values needed to perform the steps in the calibration procedure and to record the calibration data. The Job Cards also serve as the official work authorization document. When the work is completed, the Job Card is used to provide feedback to the Work Control Center for updating the computer database, (see Figure 15).

\subsubsection{Responsibilities}

Cognizant Engineers are responsible for determining if instruments require calibration recall. They are responsible for completing the Instrument Data Sheet (J-9 form) and the Calibration Data Sheet (J-10 form); requesting support from the Responsible Work Groups; and for furnishing necessary technical manuals and operation procedures, (see Figures 16 and 17).

The Work Control Center is responsible for issuing Instrument Calibration Recall Job Cards; tracking the status of instruments; controlling the database to ensure timely recall; and providing traceability. The database is used to manage information, maintain an index of instruments, provide forecasts of instruments due for recall, maintaining a record of items performed, and storing data history. Responsible Work Groups are responsible for performing the tasks as described by the Job Cards, and for filling out the Job Cards when the work is completed.

\subsubsection{Procedure}

The Cognizant Systems Engineering Group initiates the Instrument Data Sheet (J-9 form), and Calibration Data Sheet (J-10 form) documents to identify the requirements for new instruments or modification to existing instruments. The Responsible Work Groups review the J-9 and J-10 forms of the new instruments to concur on the Instrument Calibration Recall requirements. The Work Control Center enters the regular routine work into the computer which then outputs Job Cards that describe the work to be performed. 
WYNS IC JOB CARD GENERATOR RUNTIME: $2 / 10 / 94===== \pm=====================0======$

PAGE:

LOOP NO.: 201-TG-142 FUNCTION DESCRIPTION: ULTRASONIC FLAW DETECTOR

CAL IBRATION

PANAMETR ICS

93115301

912 OFFO

N/A

LAST DONE
$3 / 19 / 93$

AREA SUPERVISOR

COMMENTS---ACTIONS TAKEN, OR PROBLEMS IDENTIFIED: FOUND WITHIN ACCEPTED TOLERANCE: YES OF ERROR (AS FOUND):

PROCEDURE SPECIAL SAFETY REQUIREMENTS:

A.1.A LOCK \& TAGOUT NOT REQUIRED
A. $1 . B$
RWP NOT REQUIRED
A. 2
REFERENCES:
A.2.A
SOP NO.: N/A
A.2.B PURCHASE ORDER NO.: AS REQUIRED
A.3 SPECIAL INSTRUCTIONS:
A.3.A CALIBRATE PER MFGR'S REQUIREMENTS

SIGN-OFF SHEET FOR : $201-T G-142$

$=======$

WORK COMPLETED:

ACCEPTED FROM WORK GROUP

TECHNICIAN - DATE - AREA SUPERVISOR TATE WORK GROUP SUPERVISOR

Figure 15. Instrument Calibration Job Card 


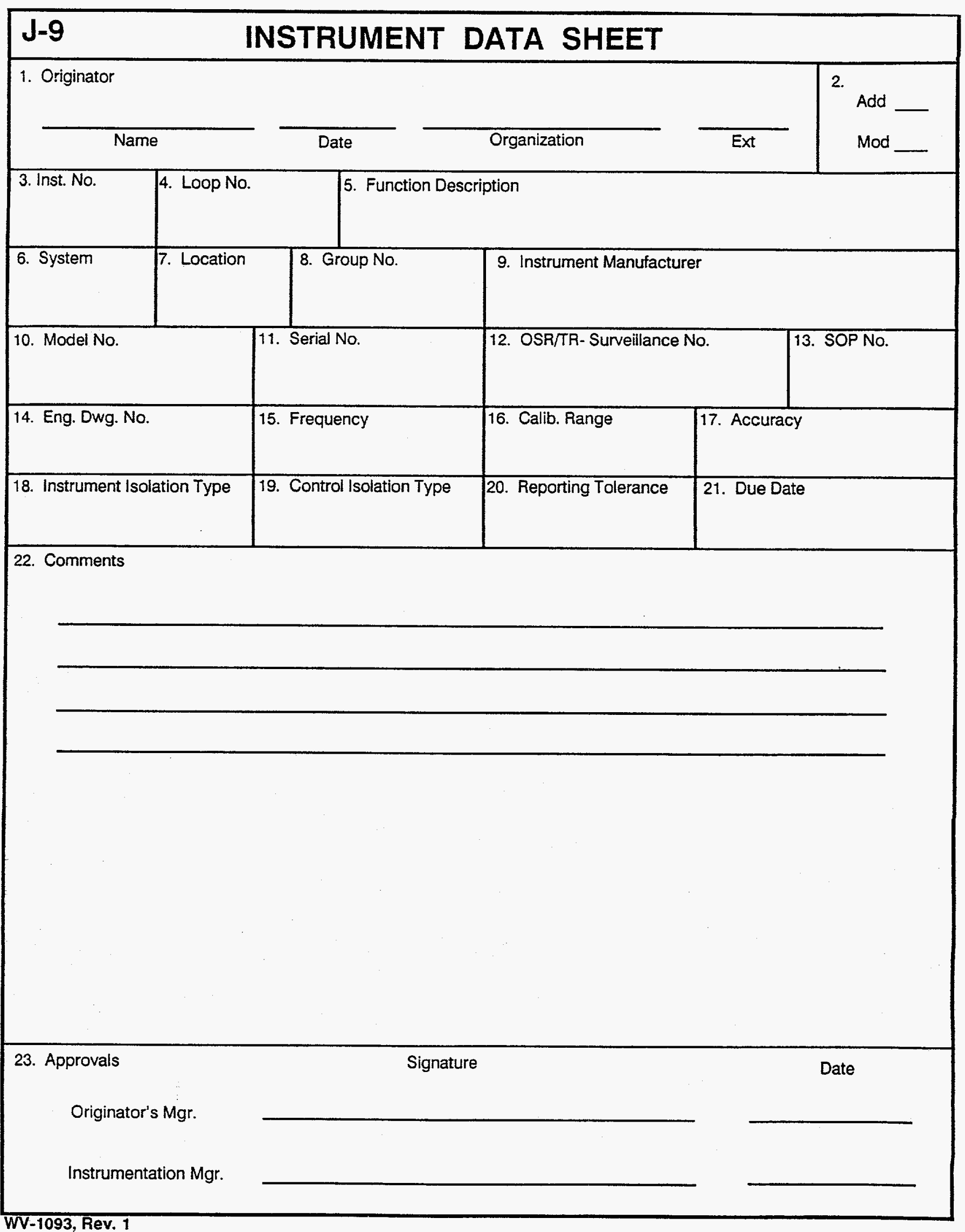

Figure 16. J-9 Form 


\section{J-10 CALIBRATION DATA SHEET}

1. Originator

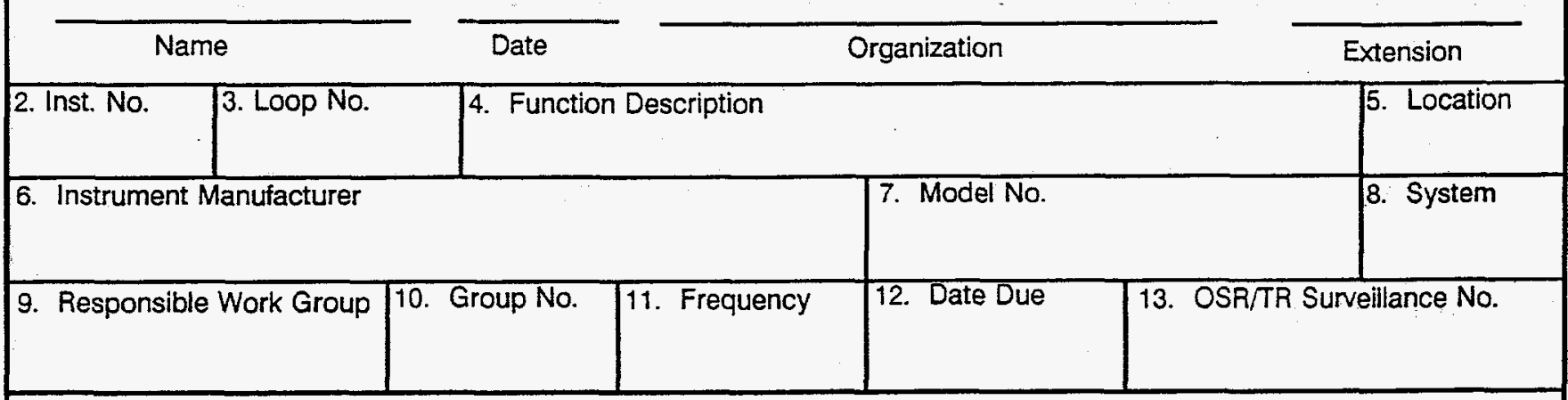

14. Task Description

15. Procedure

1. Special Safety Requirements:

1a. Lock \& Tagout Required: Yes

1b. RWP Required: Yes No No

2. References

2a. SOP No.

2b. Purchase Order Number

3. Special Instructions

16. Approvals

Originator's Mgr.

Instrumentation Mgr.

Quality Assurance

WV-1094, Rev. 2

Figure 17. J-10 Form 


\section{J-11 INSTRUMENT CANCELLATION, SUSPENSION, REACTIVATION}

1. Originator

Name

Date

Organization

Extension

2. Required Action

$\square$ Cancel $\square$ Suspend $\square$ Reactivate

\begin{tabular}{|l|l|l|}
\hline Inst/Loop No. & Effective Date & \\
\hline & & \\
\hline & & \\
\hline & & \\
\hline & & \\
\hline & & \\
\hline & & \\
\hline & & \\
\hline & & \\
\hline & & \\
\hline
\end{tabular}

3. Comments

4. Approvals

Signature

Date

Originator's Mgr.

Operations Mgr.

Work Group Mgr.

WV-1095, Rev. 0

Figure 18. J-11 Form 
Two weeks prior to the first day of each month, a list of upcoming Instrument Calibration Recall work items is sent to the Responsible Engineering Groups and Responsible Work Groups to be reviewed and incorporated into their schedules. One week prior to the first of the each month the Job Cards are issued to the Responsible Work Groups. The work tasks are performed in accordance with procedures described on the Job Cards. Work Group Supervisors sign the Job Cards when the work tasks are completed. The Job Cards are then forwarded to the Work Control Center to be processed and recorded into the history database. All completed Job Cards are then transferred to Records Management for storage and retrieval.

\subsubsection{Temporary Waiver}

All Instrument Calibration Recall work tasks are performed as scheduled unless a temporary waiver has been approved by the Work Group Supervisor and Area Supervisor. An Instrument Calibration Recall activity can not be waived two consecutive times, unless there is justification for not performing the Instrument Calibration Recall more that one frequency interval, in which case a request for suspension is submitted, (see Figure 18).

Safety related instruments associated with Instrument Calibration Recall activity identified in a Safety Analysis Report are category I items. These items are performed as scheduled. Occurrence Reports or Critiques are prepared if the work tasks cannot be performed as scheduled.

\subsubsection{Cancellation or Suspension}

Request to cancel or suspend an Instrument Calibration Recall activity is accomplished by filling out a J-11 Form. This will prevent the Job Card from being issued, and the affected item will not appear on another job card or schedule until a reactivation date is entered into the database. Justification for suspension or cancellation is limited to the following conditions:

- Instrument is out of service for repair.

- Instrument is in use, to perform an Instrument Calibration Recall would require a process shutdown.

- Instrument is located in an inaccessible portion of the plant (i.e., cells, high radiation areas, etc.) that prevent Instrument Calibration Recall performance until personnel access is restored.

- Instrument has been removed from service permanently, or for an extended period of time.

\subsubsection{Revision and Change Control}

The manager of the Cognizant Systems Engineering, Operations, or a Responsible Work Group may request changes to the Instrument Calibration Recall procedure. Instrument Calibration Recall procedures are modified by a Field Change (J-3 form), and approved by the same organization that approved the original procedure.

\subsubsection{Instrument History Card}

Standard Instrument History Cards are maintained by the Work Control Center. Each time work is performed on an instrument, the instrument component number, instrument description, date, work description, mechanic and manhours used to complete the work are recorded on the History card. 


\subsection{PLANNING AND SCHEDULING}

Effective operation of the West Valley Demonstration Project is achieved through the use of a series of plans and schedules. Plans define the programmatic missions of the West Valley Demonstration Project and project activities several weeks in advance. Near-term schedules show detailed activities necessary to accomplish the programmatic missions and to maintain and operate the West Valley Demonstration Project for a period of less than one week. Site wide Plan-of-the-Week/Plan-of-the-Day meetings are held in order to eliminate the need to hold satellite meetings throughout the site.

The Plan-of-the-Week/Plan-of-the-Day system is a fully automated, real time, interactive on-line system that is used to plan and schedule work activities on a daily basis. Because it operates interactively in a real time environment, the system is used as an evaluation tool for determining the impact of work activities as they are added or deleted from the Plan-of-the-Week/Plan-of-the-Day schedules.

The planning and scheduling of work orders are controlled through a series of weekly and daily planning \& scheduling meetings. The Plan-of-the-Week is a detailed schedule that documents activities that are planned for one week (Monday through Sunday). The Plan-of-the-Week lists each activity and resources required to perform each activity for the week. The Plan-of-the-Day schedule shows the status and configuration of the daily support work and provides the direction for the daily operation of the assigned tasks.

Work activities are generally submitted to the Work Control Center on Work Orders, in advance of their actual required performance date to allow sufficient time for planning. The Plan-of-the-Week/Plan-of-the-Day system utilizes the Open Items Database as a source of information for most of the work to be scheduled. Because of emergent work items and other unforeseen problems, it is sometimes necessary to deviate from a planned schedule. A certain amount of unplanned work is expected every day, and the impact is carefully evaluated before actual changes are made in the Plan-of-the-Week/Plan-of-the-Day schedules.

\subsection{Plan-of-the-Week}

Plan-of-the-Week meetings provide schedules for the following week activities. The Plan-of-the-Week schedules are based on Work Orders, preventive maintenance schedules, construction project schedules, carryover work from the previous week, and from unplanned emergent work. Site supervisors and engineers, who have knowledge of the West Valley Demonstration Project operation and the authority to schedule work activities, attend the Plan-of-the-Week meetings and take part in the scheduling process.

The function of the Plan-of-the-Week is to review the upcoming week's work activities, and ensure the support resources will be available at the specified time when required.

\subsection{Plan-of-the-Day}

The Plan-of-the-Day process is very similar to the Plan-of-the-Week, information from the same database as the Plan-of-the-Week is selected from the Mainframe and down-loaded to the Plan-of-the-Day application on the Computer.

At the Plan-of-the-Day meeting, the Work Group designees refine the Plan-of-the-Week plans, review the current days' activities planned at the Plan-of-the-Week meeting as well as new and emergent work that has surfaced since the Plan-of-the-Week schedule was developed. Manhour requirements are also evaluated and planned for the upcoming day. As the resources are distributed over the three shifts, manhour totals are accumulated and displayed on an overhead screen, (see Figure 19). 
If WC\# FRS-9300784-I/WO = POW/POD SCHEDULE $=$, WO: IWP:X RWP:X start 07-Feb-94 ᄀ \| LOC:FRS SUPPORT TN-BRP/REG CASK MODIFICATION OPERATIONS, LOC: FRS PRI:3 \| $\|$ MON-03/07TTUE-03/08TWED-03/09TTHU—03/10TFRI-03/11\| ||RESOURCE RMH SMH S|QTY S F HRS|QTY S F HRS|QTY S F HRS/QTY S F HRS|QTY S F HRS\#

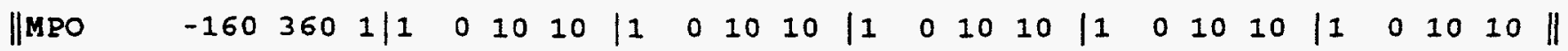

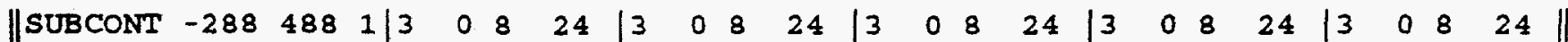
\begin{tabular}{||l|l|lllll|lllll|lllll|lllllllll||} 
|RSTECH & -10 & 108 & $1 / 1$ & 0 & 4 & 4 & 1 & 0 & 4 & 4 & 1 & 0 & 4 & 4 & 1 & 0 & 4 & 4 & 1 & 0 & 4 & 4 & $\|$
\end{tabular} ||LYDBCKER $-12 \quad 1211$

$\| Q A \quad-2 \quad 2 \quad 11$

$\|$

$\|$

$\|$

If $(A l t+F 9$ out Weeks $)$ = Manhour summary (Alt+F4 set range)=Total Friday (Alt + R1) tㅔ

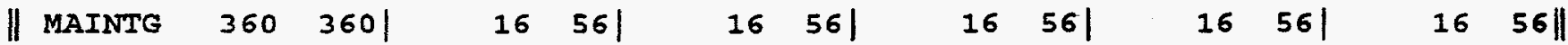

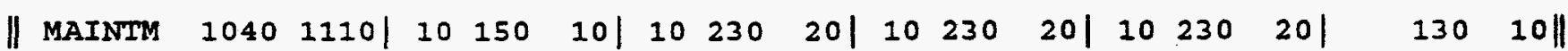
\begin{tabular}{||llllllllllllllllll|} 
MAINTI & 360 & $360 \mid$ & 8 & 56 & 8 & 8 & 56 & 8 & 8 & 56 & 8 & 8 & 56 & 8 & 8 & 56 & $8 \|$
\end{tabular}

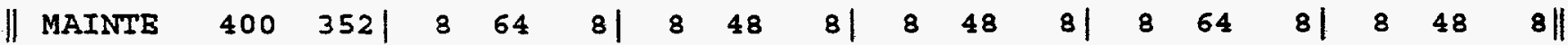

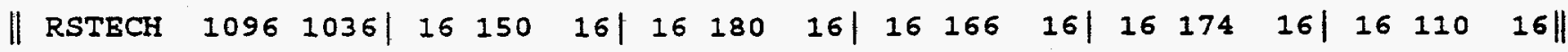

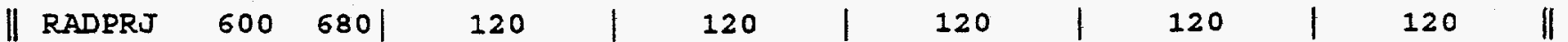
|| WMO $\quad \begin{array}{llllllllllllllll}1090 & 1060 \mid & 120 & 30 \mid & 20 & 210 & 30 \mid & 20 & 210 & 30 \mid & 20 & 210 & 30 \mid & 20 & 110 & 0\|\|\end{array}$ \begin{tabular}{||lllllllllllll}
$\mid \mathrm{HAZ}$ & 200 & $140 \mid$ & 0 & $\mid$ & 40 & $\mid$ & 40 & $\mid$ & 40 & $\mid$ & 20 & $\|$
\end{tabular} $\begin{array}{llllllll}|| & Q A & 280 & 280 \mid & 56 & \mid & 56 & \mid\end{array}$ \begin{tabular}{|lllllllll}
|| & QACONST & 280 & 240 & 48 & $\mid$ & 48 & $\mid$ & 48
\end{tabular}

Figure 19. Resource Distribution 
When accumulated resources exceed the pre-established manpower availability, the computer system will highlight the total as a warning of a manhour overload. When an overload is indicated, the Work Groups evaluate different scenarios to resolve the problem, such as changing staffing levels assigned to perform the activities, adding resources (including overtime), or rescheduling work items.

Once the meeting attendees have agreed on a schedule, the computer system generates a Plan-of-the-Day schedule. The Plan-of-the-Day schedule indicates, through a series of barcharts for each assigned Work Group, task descriptions, assigned resources, work shifts, and anticipated time required to perform the task, (see Figure 20). 


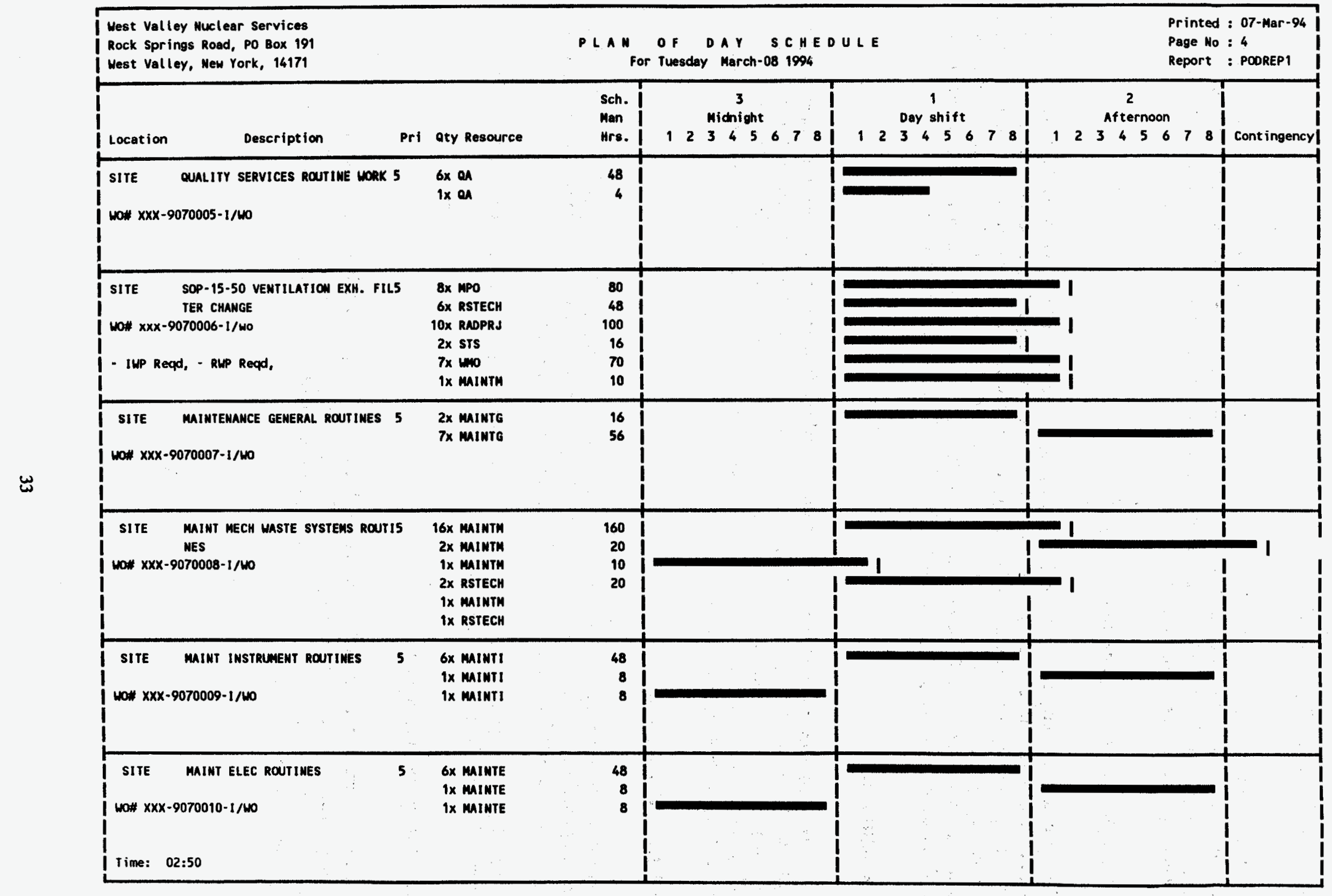

Figure 20. Plan-of-the-Day Schedule 


\subsection{SYSTEM DESCRIPTION}

The West Valley Nuclear Services Co., Inc.-Work Control Center Automatic Data Process establishes, maintains, and utilizes the work control database through the Open Items Tracking system which is a self contained system on a mainframe ARTEMIS 9000 . The system initiates, tracks, and properly closes out internal and external commitments, as well as all work orders.

\subsection{Open Items Tracking System}

The Open Items Tracking System is specifically designed to address commitment items and non-recurring work. All work orders, shop orders, surveillance, and audits are handled through Open Items Tracking System. The Open Items Tracking System module is the core of the Work Control System. It provides an automated system for controlling work packages. Screens and reports are provided for review and modification within the Open Items database. Open Items Tracking System utilizes the standard ARTEMIS relational database features, as well as locally developed applications software that allows the use of multiple-level menus.

\subsection{Data Entry}

Open Items Tracking System provides data-entry screens which allow users to input new work requests on-line. The data-entry screens allows users to navigate through the screens and data fields by using either the tab keys, or directional (arrow) keys. Open Items Tracking System also has data criteria and validation tables set up to validate each record. If the user attempts to enter a record without meeting all the criteria, they will be denied access and prompted to enter valid data.

\subsection{Recurring Reports}

The Open Items Tracking System module generates a number of weekly reports and graphics packages. These recurring requirements are controlled and generated by a batch program that not only creates all the necessary output, but directs traffic in and around the Open Items Datasets and Archives.

The batch program operates during night hours, without operator supervision. (It executes its requirements with no input by Work Control Center personnel.)

\subsection{Management Analysis}

With a management analysis module, Open Items Tracking System provides the capability for work measurement, statistical and trend analysis, in addition to other performance measurement analysis used as management tools. Open Items graphic reports include work load trend curves, work load histograms, and performance summary piecharts. 